\title{
Research Paper \\ A qualitative assessment of strategies affecting adaptability in the post-divorce adaptation process: knowledge based on the experience of divorced women
}

\section{Farahnaz Jeloyari $^{1}$, Somayeh Kazemian ${ }^{2}$, Ebrahim Naeimi ${ }^{2}$, Abdolah Motamedi ${ }^{3}$}

1. Ph.D Student of Counseling, Department of Counseling, Allameh Tabataba'i University of Tehran, Tehran, Iran.

2. Assistant Professor, Department of Counseling, Allameh Tabataba'i University of Tehran, Tehran, Iran.

3. Full Profesor, Department of General and Clinical Psychology, Allameh Tabataba'i University of Tehran, Tehran, Iran.

Citation: Jeloyari F, Kazemian S, Naeimi E, Motamedi A. A qualitative assessment of strategies affecting adaptability in the postdivorce adaptation process: knowledge based on the experience of divorced women. J of Psychological Science. 2021; 20(105): 15131534.

URL: https://psychologicalscience.ir/article-1-1399-fa.html
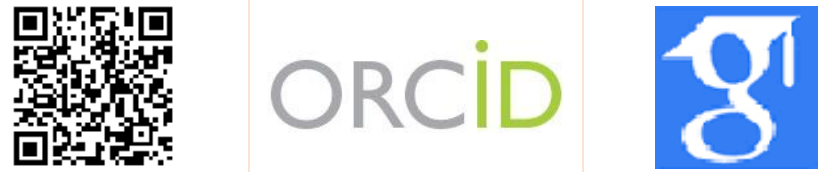

\section{A R T I C L E I N F O}

Keywords:

Adaptability, adjustment, divorce, Knowledge Based on the Experience, divorced women

Received: 04 Sep 2021 Accepted: 30 Sep 2021 Available: 22 Nov 2021

\section{A B S T R A C T}

Background: For many women, divorce means coping with extreme stress and emotional instability. To meet the challenges after divorce, divorced women need to be more resilient using different strategies. Almost all studies conducted in Iran with the subject of life after divorce have dealt with the process of adaptation and adaptation has been less considered as the gateway to adaptation. Aims: The aim of this study was to discover effective strategies in the process of adaptation during post-divorce adjustment in divorced women.

Methods: This research was conducted with a qualitative approach and contextual theory method in 2020 and 2021 in Tehran. The population or field studied in this study included all divorced women in Tehran in 2020 who have passed at least 3 years of legal divorce (who have the opportunity and experience to face the challenges of life after divorce and the possibility of entering the process of adaptation after divorce. The study sample was saturated by selecting 12 divorced women using snowball sampling. Semi-structured interviews were used to collect data. The interviews were analyzed using the systematic method of Corbin and Strauss.

Results: Analysis of participants' experiences leads to the identification of 7 main categories of building a new identity, interacting with divorce, managing post-divorce challenges, engaging in social activities (environmental influences), buffer (protective factors), spiritual-religious confrontations and Coping with factors out of control.

Conclusion: The results showed that divorced women 's use of internal and external factors can help to adapt to life after divorce and put them on the path of adjustment. Understanding knowledge based on divorced women's experience of post-divorce consequences and how to adapt to it, as presented in the present study, can help divorced women, counselors and therapists involved in this area to make gender-based decisions and interventions.

* Corresponding Author: Somayeh Kazemian, Assistant Professor of Counseling, Department of Counseling, Faculty of Psychology and Educational Sciences, Allameh Tabataba'i University of Tehran, Tehran, Iran.

E-mail: S.kazemian@atu.ac.ir

Tel: (+98) 2144737510

2476-5740/ (C) 2021 The Authors. This is an open access article under the CC BY-NC-ND license

(https://creativecommons.org/licenses/by-nc/4.0/). 


\section{Extended Abstract}

\section{Introduction}

As divorce increases in family life, its effects and consequences threaten the life of society and its health more than ever. Among these, we can consider the consequences of divorce on divorced women. Divorce, as a period of change, changes the course of women's lives, On the other hand, after divorce, the social network around divorced women is largely lost or diminished (Konstam et al., 2016) and many of them feel lonely (Aartsen \& Jylha, 2011) and she is ashamed and sinful (Orth et al., 2010). The feeling of loneliness caused by divorce is related to the loss of intimate relationships and to people's mental evaluation of social isolation (Shankar et al., 2017) and leads to mental health problems and the risk of mental disorders such as depression (Cacioppo et al., 2010) and increases cognitive deficits (Shankar et al., 2013).

Studies related to divorce have shown that society is more strict with women after divorce. In addition, the psychological consequences of divorce for women lead to more harm, and women struggle with these consequences for years after divorce (Saadati et al., 2017 \& Mandemakers et al., 2010). Divorce also brings with it many social, economic, cultural, and even physical challenges. To deal with these major challenges and harms, it is necessary for divorced women to become more resilient by using different strategies during the post-divorce period (Khan \& Hamid, 2020 \& SadeghiFasa'I \& Isari, 2013). According to what was reviewed, one of the most important issues for divorced women is their adaptation to the situation after divorce. Research shows that some women adapt well after divorce and some do not (Mirzazadeh et al., 2012). Most divorced women have poor adaptation to post-divorce conditions. These divorced women see divorce more as the end point of a long process, and feelings of inferiority and personality are among the consequences they experience after divorce (Ghafoorian Nourozi et al., 2013). For many women, the end of married life is a huge stress and emotional instability, but adaptation to it comes in many forms. The intensity and duration of the adaptation process may be related to several factors, one of which is individual resources (Amato, 2010). Some related studies have shown that people who have endured less stress in their married life have more problems coping with divorce (Amato \& Hohmann-Marriott, 2007). Another factor is the greater desire of one of the parties to separate. It has been hypothesized that the person initiating the separation will feel more in control of the situation, and this may help the person to better adapt to the divorce (Hewitt, B., \& Turrell, 2011 \& Wang \& Amato, 2000). How to experience divorce, the continuation of conflicts with the exspouse and the increase of financial problems (Kramrei et al., 2007 \& Braver et al., 2006), People's attachment style and the degree of preoccupation and mental conflict with the ex-spouse also play an important role in adaptation (Yarnoz-Yaben, 2010). Almost all studies conducted in Iran with the subject of life after divorce have dealt with the process of adaptation and adaptation has been less considered as the gateway to adaptation. The importance of the early years after divorce and the need for adaptation, or as a prelude to adaptation, requires researchers to go beyond quantitative and purely focused research on adaptation, because until adaptation is achieved, adaptation will not take shape. Therefore, the present study with a qualitative approach seeks to answer the fundamental question of what are the effective strategies on the adaptation process during postdivorce adjustment based on the knowledge based on the experience of divorced women?

\section{Method}

The present study was conducted with a qualitative approach and contextual theory (GT) method using a systematic method (Corbin \& Strauss, 2014). The population or field studied in this study included all divorced women in Tehran in 2020 who have passed at least 3 years of legal divorce (who have the opportunity and experience to face the challenges of life after divorce and the possibility of entering the process of adaptation after divorce Be employed and have children, be their first experience of divorce and, while willing to participate in research, do not have an acute mental disorder (based on DSM5 and clinical psychologist certification) and, most importantly, in 


\section{Monthly Journal of Psychological Science}

the afterlife Divorce has reached adaptability (based on the participant's personal acknowledgment of the divorce adaptation and its confirmation in the initial interview with the interviewing researcher). Other inclusion criteria in this study were at least a diploma and being in the age range of 25 to 55 years. To achieve the desired sample of the study, targeted sampling strategy and snowball method were used to select the desired samples and units.Data in the present study were saturated after interviews with 10 divorced women; But to be sure, interviews continued for up to 12 participants. Exclusion criteria were the reluctance of the participant to participate in the research and to refrain from providing information during the interview. In this study, semi-structured indepth interviews were used to collect data. In addition to the interview method, other methods of data collection were used in qualitative studies such as field note taking and observation. Interviews were conducted over a period of 48 to 63 minutes, depending on the mood, tolerance threshold and interest of the participants. The questions of the present study were generally general and open-ended due to the nature of the research method (contextual theory method), so they were asked to gain knowledge based on the experiences of divorced women about effective strategies in the adaptation
Vol. 20, No. 105, Autumn(December) 2021

process during post-divorce adjustment. What effective measures or strategies have you used to adapt to your divorce, or how has the individual used individual and environmental factors to adapt to the divorce? Systematic contextual theory method was used to analyze the data. According to the systematic approach of Strauss and Corbin, the data were analyzed in a regular and at the same time continuous process of data comparison.

\section{Results}

To examine the participants' experiences in the main research question, the data obtained from semistructured interviews with 12 divorced women were analyzed. After analyzing the content of the interviews conducted by the systematic method of Corbin and Strauss, 7 main categories, 23 subcategories and 100 open codes were extracted from their experiences. The effective strategies extracted in the adaptation process of divorced women in the present study include building a new identity, interacting with divorce, managing post-divorce challenges, engaging in social activities, buffer, spiritual-religious confrontations and $\mathrm{C}$ oping with factors out of control. Coming with agents was out of control. The main and sub-categories extracted are listed in Table 1.

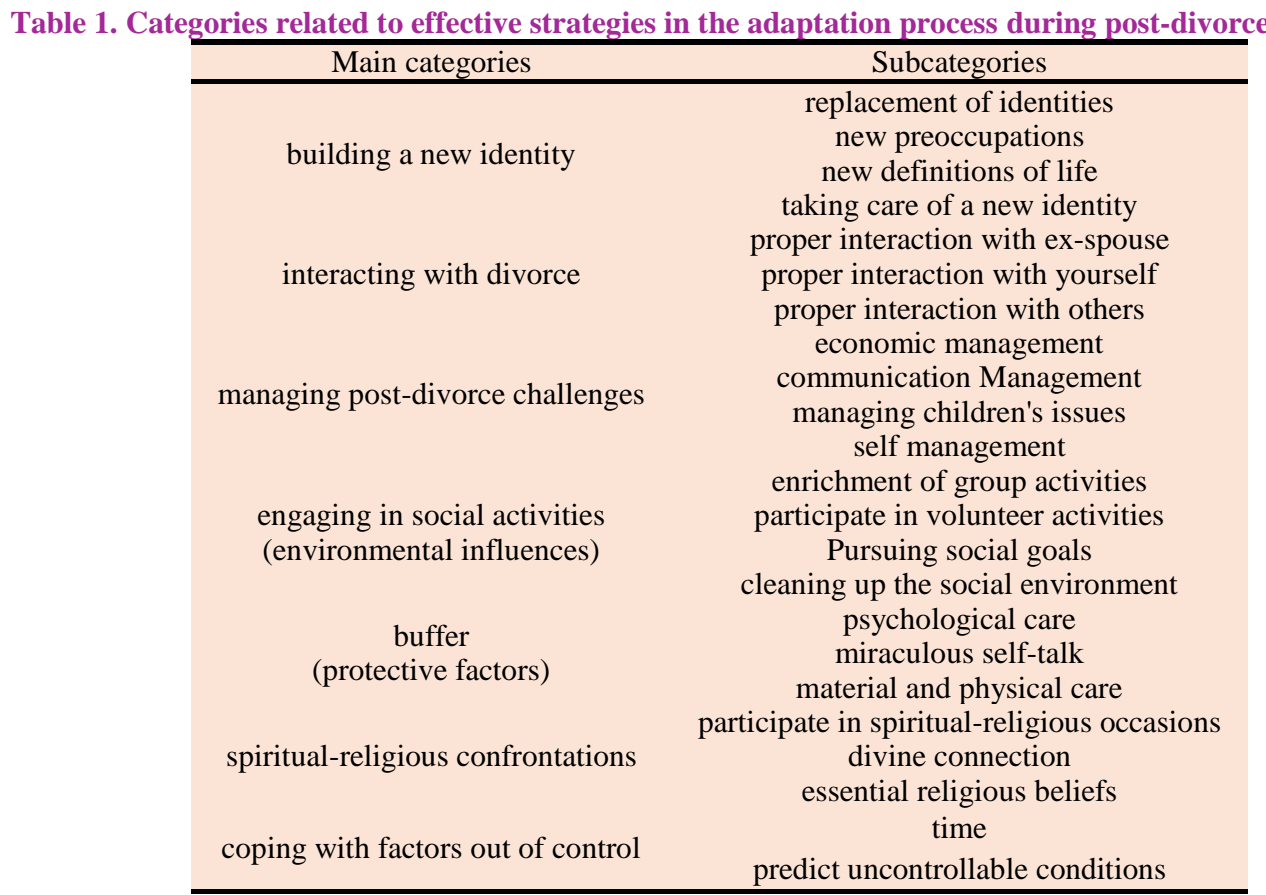




\section{Conclusion}

The aim of this study was to obtain knowledge based on the experience of divorced women of strategies affecting adaptability in the post-divorce adjustment process. Despite the increase in divorce rates and changes in its acceptance in Iranian society, the phenomenon of divorce is still among the situations that lead to major losses in physical, psychological, social and even spiritual dimensions. This issue, due to the cultural context of Iranian society, puts more pressure on women and slows down their adaptation and then adaptation to living conditions after divorce. The first major category discovered was "building a new identity." While for most women, marriage is an important part of identity; Hence, divorce will be a process of losing that part of their identity. Thus, the participating women were able to redefine their "self" after the divorce, creating a new identity that helped them move in a new direction. The second category identified in the path of adaptation to divorce in the lives of divorced women was "their proper interaction with the phenomenon of divorce." In confirmation of what has been discovered in this category, Simmons et al. (2014) believe that the quality and nature of relationships with ex-spouses affect the positive adjustment in the days after divorce. In addition, Colic and Casa (2014) concluded in their study that the type of relationship with an ex-spouse, lack of hostility and anxiety, or a friendly relationship as a source of support can facilitate post-divorce adjustment. The third major issue in coping with divorce, narrated by divorced women, was "managing post-divorce challenges." Managing economic issues leads a divorced woman to believe that she feels more in control of life, which increases their selfconfidence and self-esteem. The fourth category extracted from the strategies affecting adaptability in the post-divorce adjustment process was "involvement in social activities (environmental influences)". It seems that participating in group activities and engaging in social interactions, while refining the psychological and emotional discharge of divorced women in the present study, helped them to go through the stages of grief and reach the stage of acceptance and adaptation to new conditions more quickly. The fifth major category identified was " buffer (protective agents)". In the present study, these protective factors, such as psychological care, miraculous self-talk, and material and physical care, act as a shock absorber for post-divorce stress and help divorced women more easily and effectively deal with problems and stress. Coping with life after divorce. The sixth category extracted in the present qualitative study was "spiritual-religious confrontations". Related research has shown that religious beliefs are emphasized because they can make the experience of the incident meaningful and easier to bear during devastating hardships. Participating in religious occasions, while providing a platform for community attendance and helping to vent their emotions, raises hope. The religious context and the existence of religious and spiritual occasions and ceremonies in all existing ethnicities accelerate and deepen this process (Web et al., 2010). The last major category derived from knowledge based on divorced women's experiences of adaptability during divorce adjustment was " Coping with factors out of control". Divorced women participants believed that some issues and problems could not be solved after divorce, so they should be temporarily accepted and adapted to.

\section{Ethical Considerations}

Compliance with ethical guidelines: This article is taken from the doctoral dissertation of the first author in the advisory department of Allameh Tabatabai University of Tehran with the Ethics ID IR.ATU.REC.1399.086 and approval date of 26/10/2020. Mandatory ethical considerations in this study include obtaining informed consent from the participants and obtaining written consent, confidentiality (using a pseudonym, for example, participant 1,2 , etc. throughout the study), respect for privacy and the right to cancel. There were participants.

Funding: This study was conducted as a $\mathrm{PhD}$ thesis with no financial support.

Authors' contribution: The first author was the senior author, the second were the supervisors and the third and forth was the advisors.

Conflict of interest: the authors declare no conflict of interest for this study.

Acknowledgments: We sincerely thank all the divorced women who participated in this qualitative research and honestly shared their experiences with us. 
بروسى كيفى راهبردهاى مؤثر بر انطباقيذيرى در فر آيند ساز گارى یّ از طلاق: دانش مبتنى بر تجربه زنان مطلقه

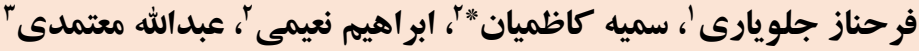

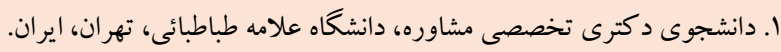

r. استاديار، گروه مشاوره، دانشكاه علامه طباطبائى، تهران، ايران.

r. استاد تمام، گروه روانشناسى بالينى و عمومى، دانشكاه علامه طباطبائى، تهران، ايران. تُان.

زمينه: طلاق براى بسيارى از زنان به معناى رويارويى با فشار روانى مفرط و بىثباتى هيجانى است. براى مقابله با جالشهاى بِ از طلاق،

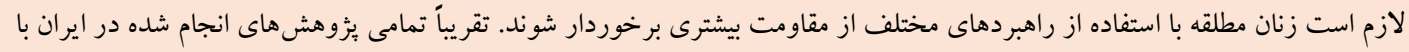

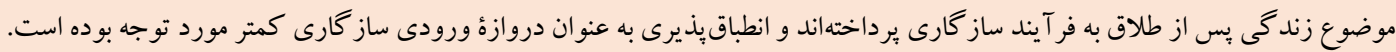
هدف: يُزوهش حاضر با هدف كشف راهبردهاى مؤثر در فر آيند انطباقيذيرى در خلال ساز گارى بـ از طلاق در زنان مطلقه انجام شد.

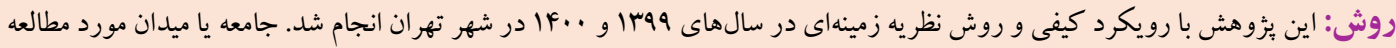

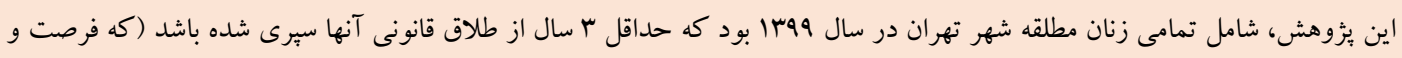
مشخصات مقاله

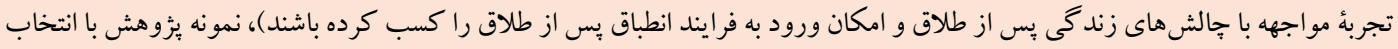

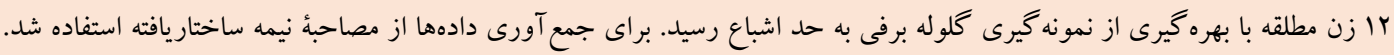

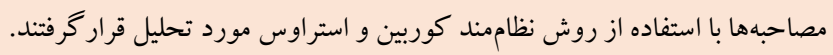

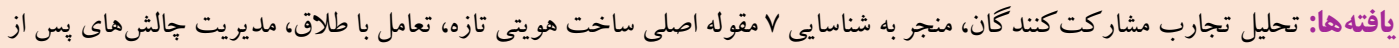
طلاق، در گير شدن در فعاليتهاى اجتماعى (تأثير ات محيطى)، ضربه گيرها (عوامل محافظت كننده)، مقابله هاى معنوى - مذهبى و كنار آمدن باعوامل خارج از كنترل شد. نتيجه كيرى: نتايج نشان داد بهره گيرى زنان مطلقه از عو امل درونى و بيرونى مى تواند به انطباق يذيرى با زندگى يس از طلاق و قرار گرقتن

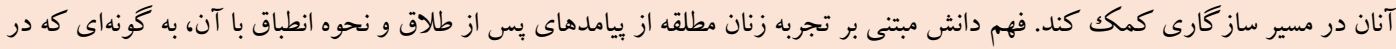

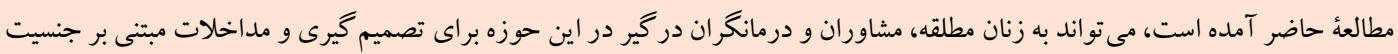


نوروزى، قنبرى هاشم آبادى و حسن آبادى، وجr|). اين نتيجه تأييد كننده

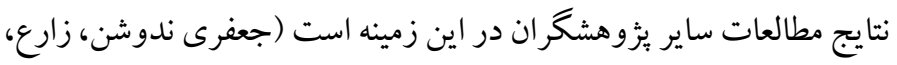

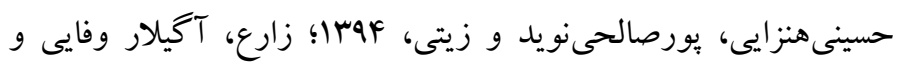

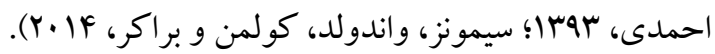

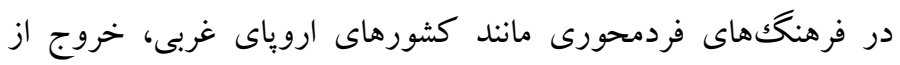
زندگى زناشويى كه فرد از آن رضايت ندارد، امرى طبيعى قلمداد شده، اما

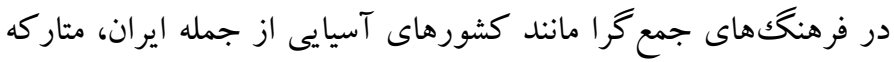

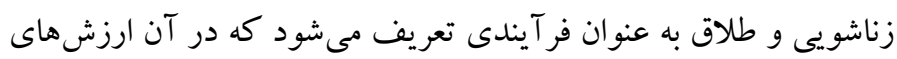

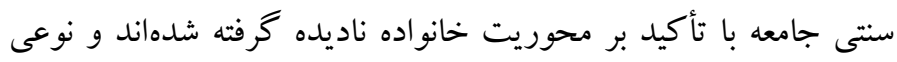
هنجارشكنى تلقى شده و بار اجتماعى فراوانى را براى فرد ايجاد مى كند.

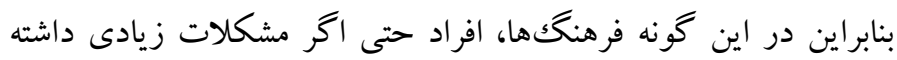

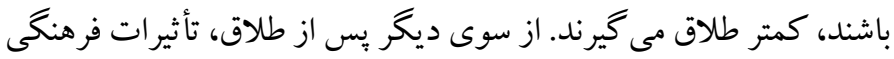

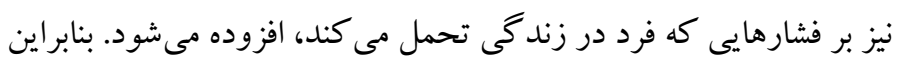

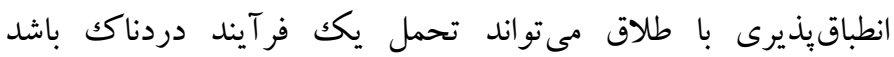

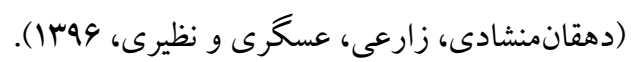
طلاق براى بسيارى از زنان به معناى رويارويى با فشار روانى مفرط و و

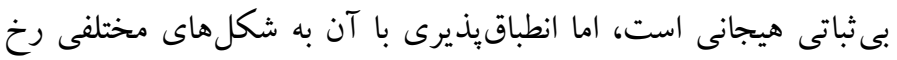

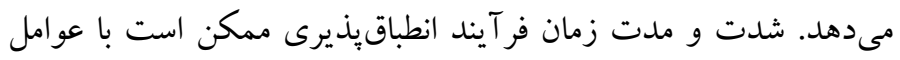
مختلفى رابطه داشته باشد كه يكى از آنها منابع فردى است (آماتو، •1. (Y).

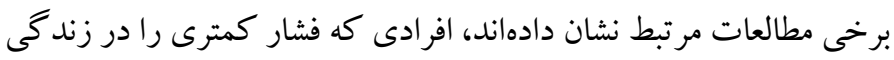
زناشويى تحمل كردهاند، مشكلات بيشترى در انطباق با طلاق دارند (آماتو

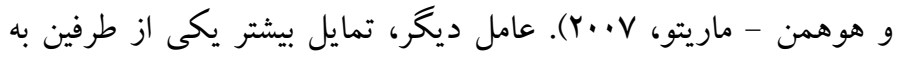
جدايى است. برخى مطالعات در اين زمينه نشان دادهاند كه همسر آغاز گر جدايى، احساس كنترل بيشترى بر امور داشته و اين امر امكان دارد به او

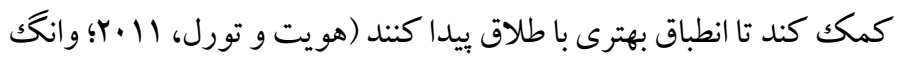

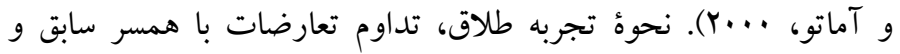

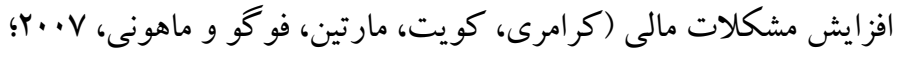

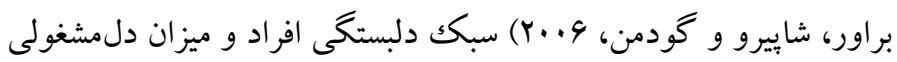
و در گيرى ذهنى با همسر سابق نيز در انطباق يذيرى با طلاق نقش مهمى ايفا

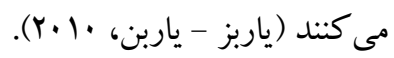

در بزوهش هاى اخير، مسيرهاى انطباق روانشناختى با طلاق به ميزان قابل

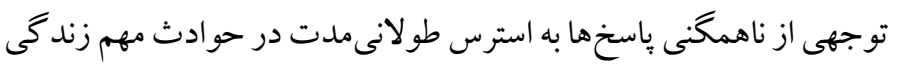

مقلفمه

به همان ميزان كه طلاق در زندگى خانوادگى رو به افزايش است، آثار و

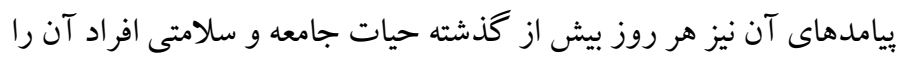

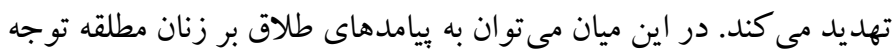

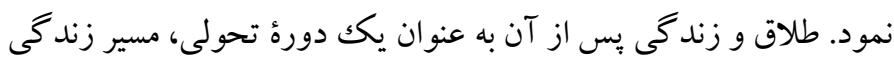

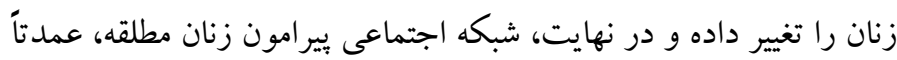

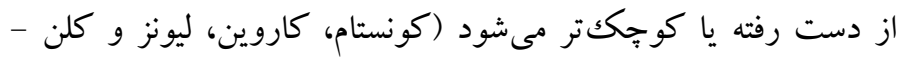

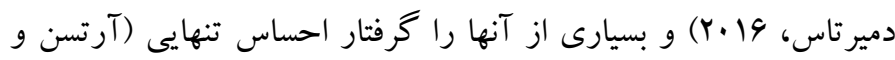

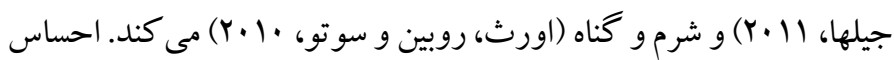
تنهايى ناشى از طلاق با از دست رفتن روابط صميمانه و با ذهنيت منفى افراد

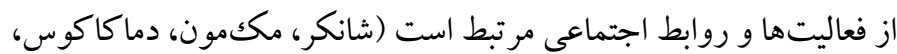

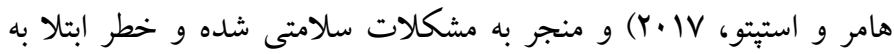

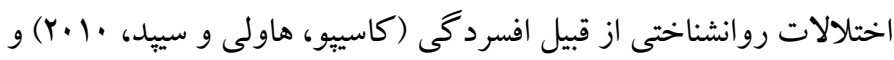

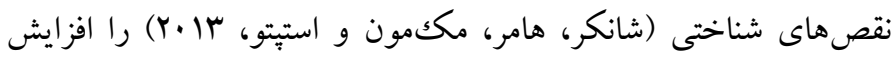
مى دهل. مطالعات مرتبط با طلاق در ايران نشان داده است، بِ از طلاق، جامعه بر زنان سختخيرى بيشترى كرده و بيامدهاى روانشناختى طلاق براى زنان، آسيبهاى بيشترى را به دنبال دارد و زنان تا سالها بعد از طلاق با باين

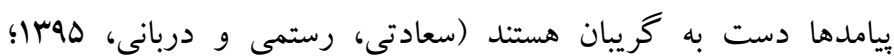

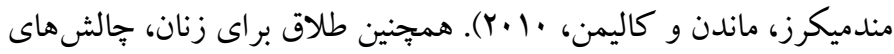

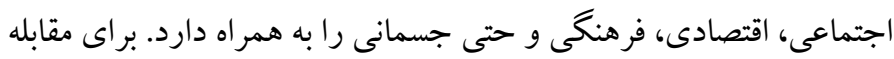

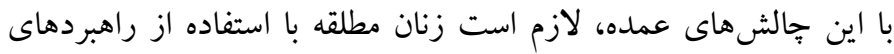
مختلف در طول دوران بس از طلاق از مقاومت بيشترى برخوردار شوند

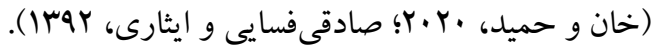
با توجه به آنجه در سطور فوق مرور شد، يكى از مسائل مهم براى زنان مطلقه، مسئله انطباق آنان با زندگى پِ از طلاق و ويامدهاى ناشى از آن است. مطالعات نشان دادهاند برخى از زنان بعد از طلاق، انطباق مناسبى ييدا كرده و برخى نيز به با آن منطبق نمىشوند (ميرزازاده، احمدى و و

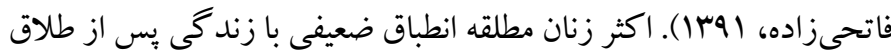

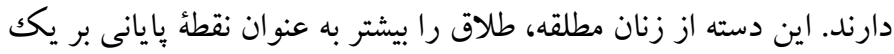
فر آيند طولانى مدت قلمداد كرده و احساس حقارت و خُرد شدن شخصيت از جمله بيامدهايى است كه آنها بعد از طلاق تجربه مى كنند (غقوريان 
زنان مطلقه برداختند. از تجزيه و تحليل دادههاى بروهش مذكور، يكك طبقهُ

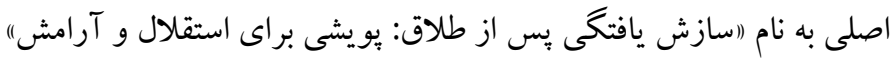

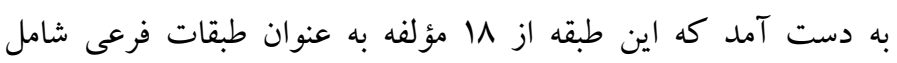

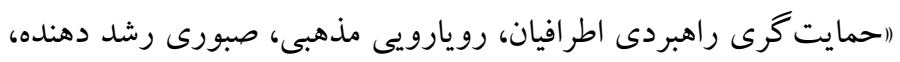

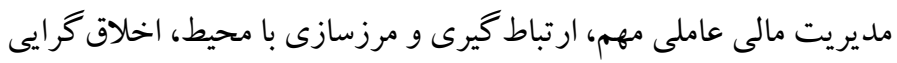

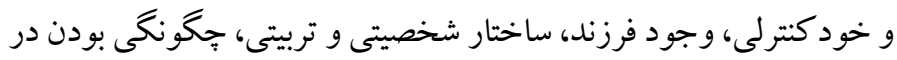

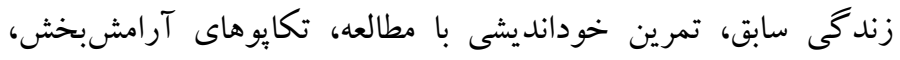
توسعه شخصى، حضور معنادار اجتماعى، بسترى براى رشد فرزندان، جستجوى كمككهاى تخصصى، شغل و تحصيل، رهايى از قفس طلاق و

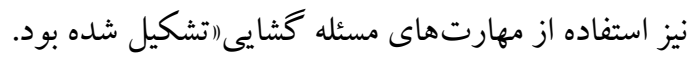

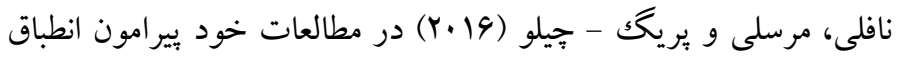

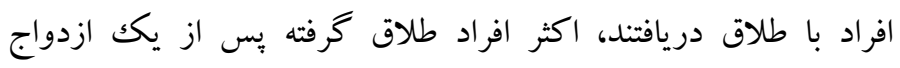

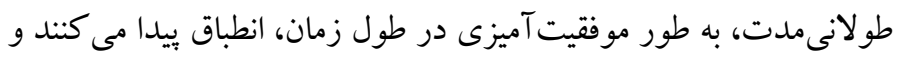

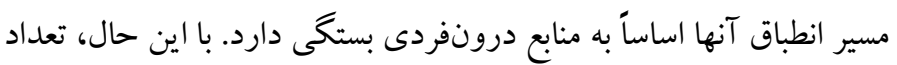

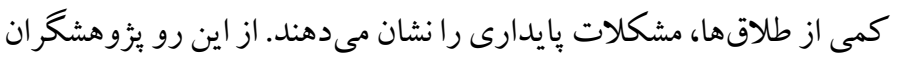
مذكور، مطالعهاى با هدف روشن ساختن مسيرهاى مختلف انطباق

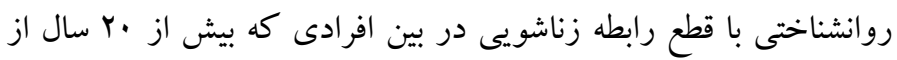

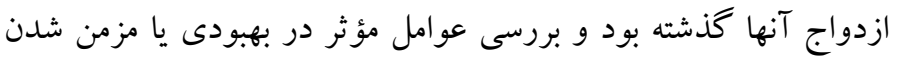

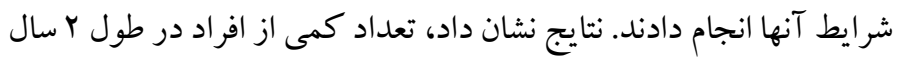
اول از گروههاى فاقد انطباق به گروههاى تطابق يافته تغيير وضعيت دادند. بريخك - جيلو، هاجيسون و مرسلى (ه) (ب) در مطالعه ديخرى به دنبال

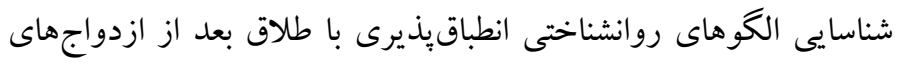

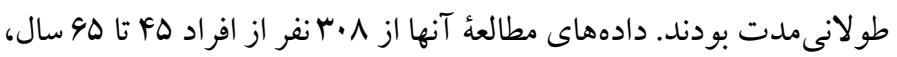

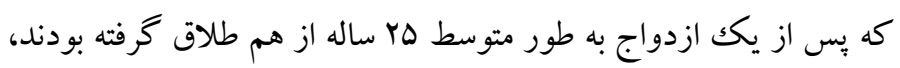

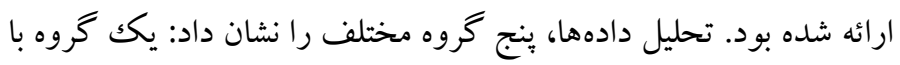

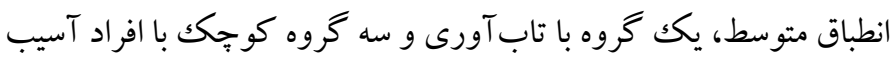
ديده. متغيرهاى تفكيك كننده بين گروهها شامل ويز گیىهاى شخصيتى، زمان جدا شدن، رابطة جديد و وضعيت مالى بود. سن، جنسيت و طول ازدواج نيز در اين روند، نقشى جانبى داشتند.

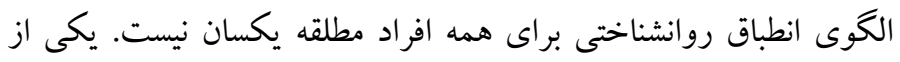

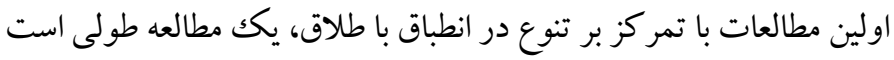

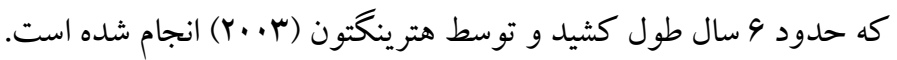

از جمله طلاق تأكيد كردهاند. به طور كلى انطباق الكويى در نظر گرفته

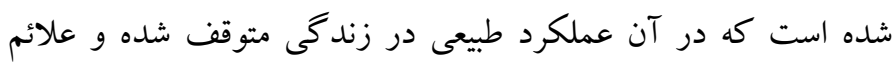

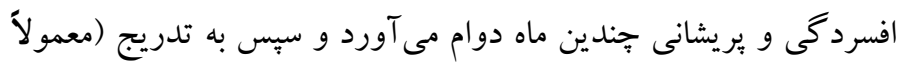

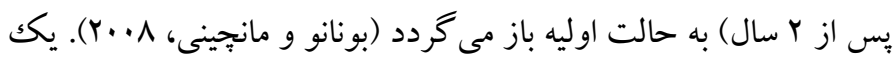

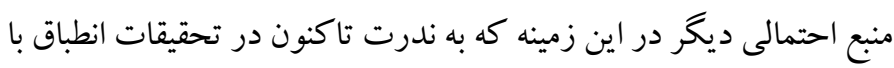
طلاق بررسى شده است، رشد شخصى متعاقب اين واقعه است. در واقع، تعداد كمى از مطالعات، احتمال تغييرات مثبت زندگ

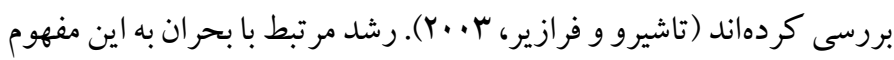

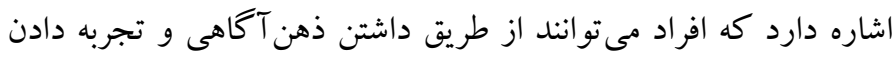

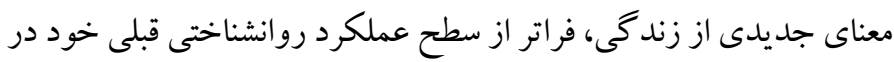

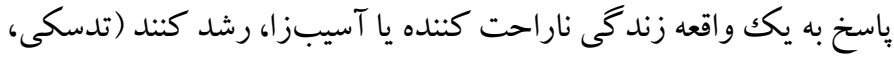

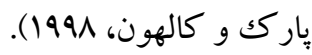

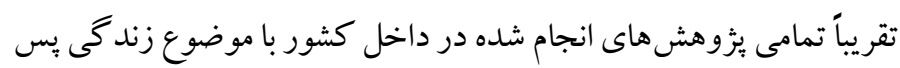

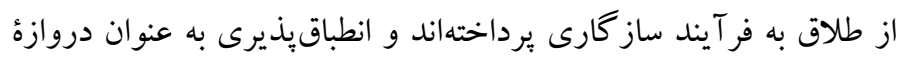
ورودى ساز كارى كمتر مورد توجه بوده است.

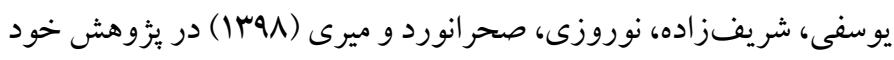

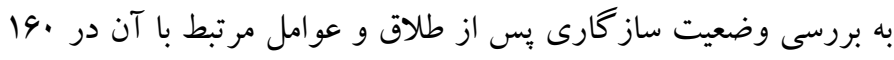

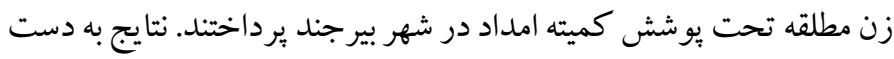
آمده در يزوهش مذكور نشان داد كه زنان مطلقه به خصوص زنه زنان خانهدار و داراى تحصيلات بايين، از وضعيت ساز گارى مطلوبى برخور دودار نيستند.

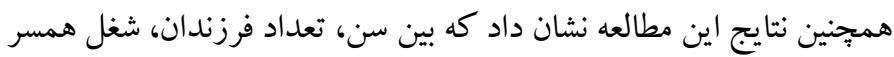

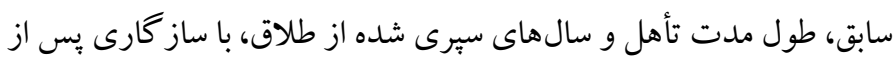
طلاق رابطه معنادارى وجود نداشت. بحر انى، بلند و صيادى (1) (1) با استفاده از روش كيفى و از طريق نظرئ زمينهاى به ارائه مدل رشد بِ از تروماى ناشى إنى از طلاق در زنان مطلقه

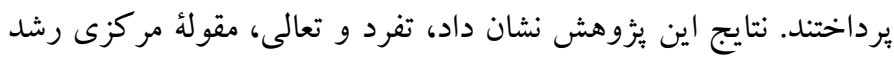

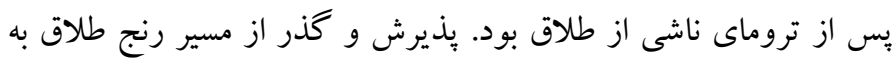

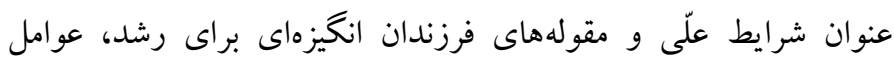

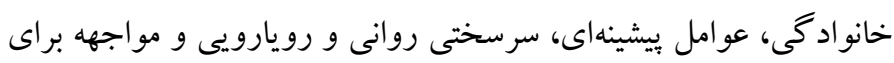
شرايط مداخلهاى استخراج شد. نظرىفر، سودانى، خجستهمر و فرهادىراد (1) (1) در يكك مطالعه كيفى

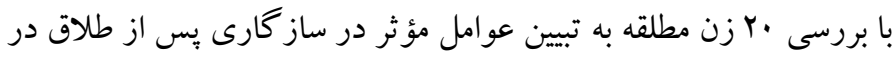


مهم تر از همه اين كه در زندگى بس از طلاق به انطباقيذيرى رسيده باشند

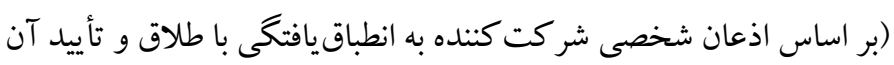

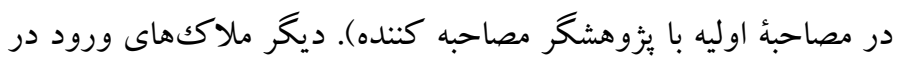

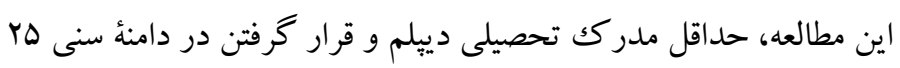

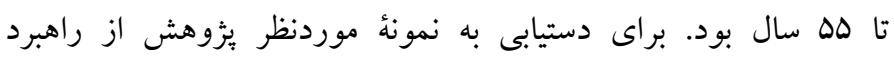

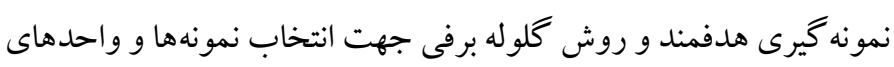

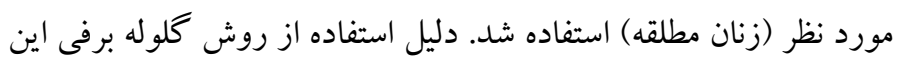

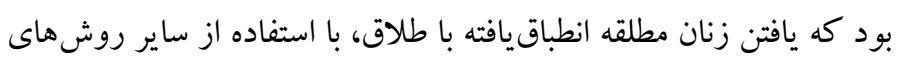

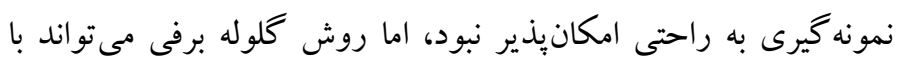

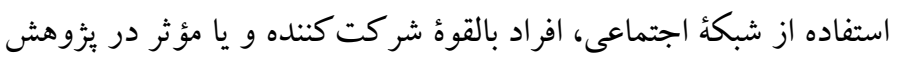

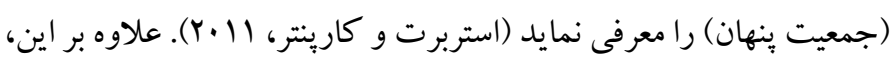

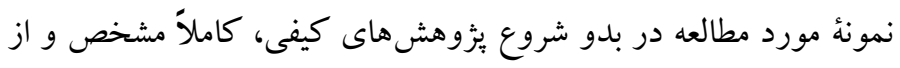

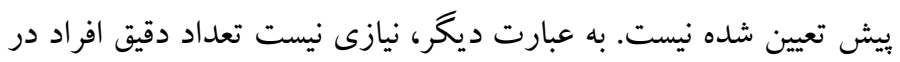

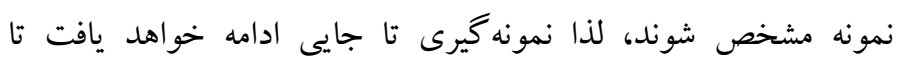

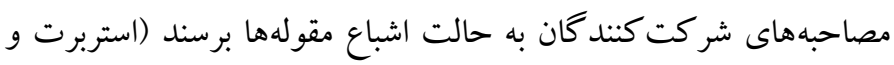

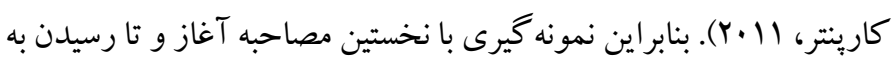

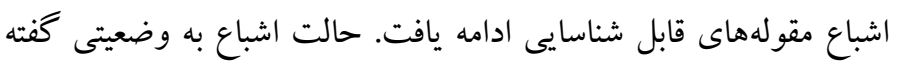
مىشود كه بِاسخهاى شركت كنند گان جديد به سؤالات مصاحبه نيمه

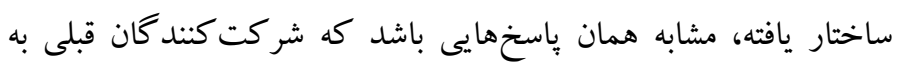

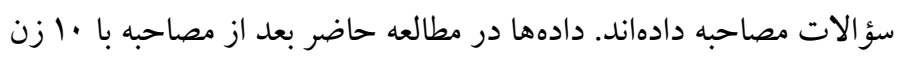

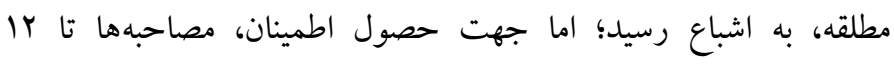
شركت كننده ادامه بيدا كرد. ملاككهاى خروج از مطالعه نيز عدم تمايل شركت كننده به شركت در بثزوهش و بازدارى از ارائه اطلاعات در حين

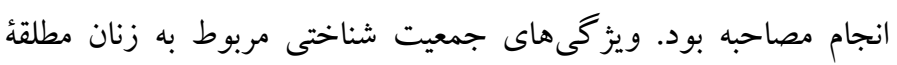

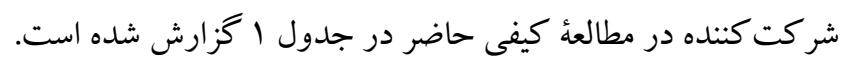

نتايج تجزيه و تحليل خوشهاى اين مطالعه (بر اساس ال متغير مانند سلامت

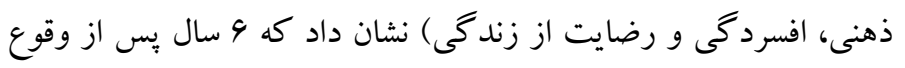

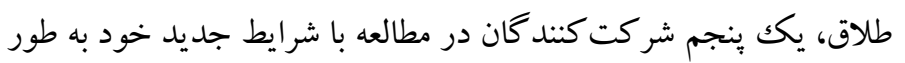
مناسبى منطبق شده بودند، در حالى كه • 1\% هنوز ناميد و افسرده بودند.

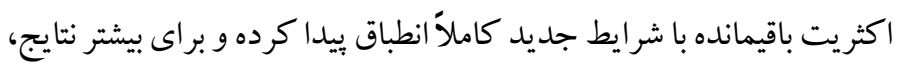
نمره متوسط كسب كردند.

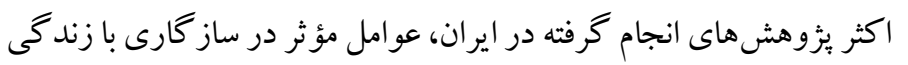

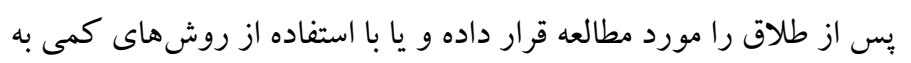

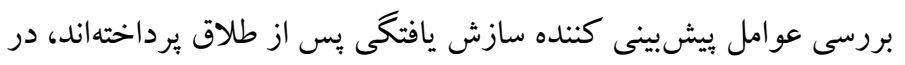

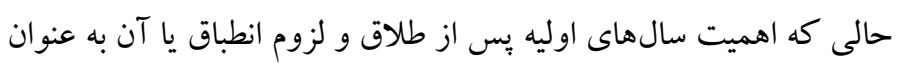

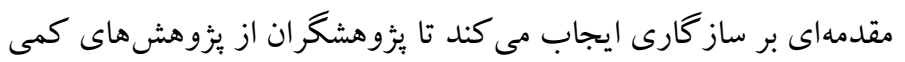

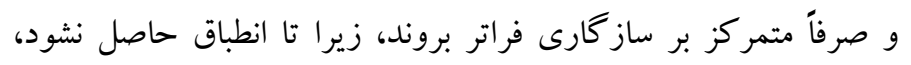

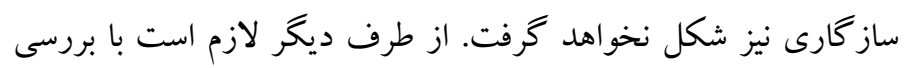

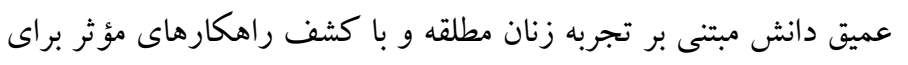

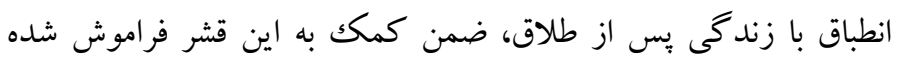

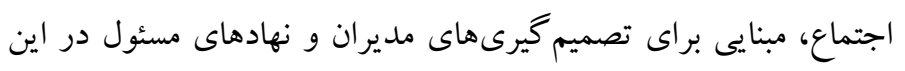

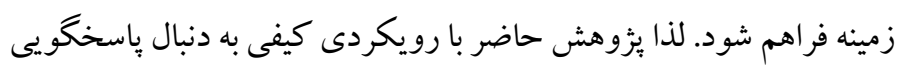

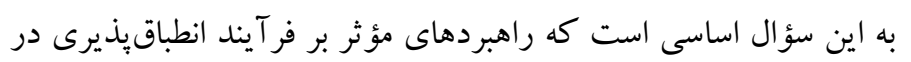

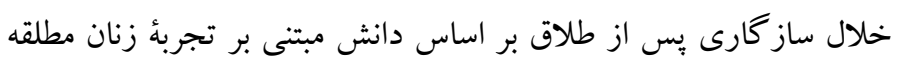

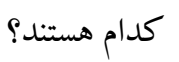
روش الف) طرح ئوهش و شر كت كنند كان: مطالعه حاضر با رويكرد كيفى و روش نظريه زمينهاى (GT) با استفاده از شيوهُ نظاممند (كوربين و

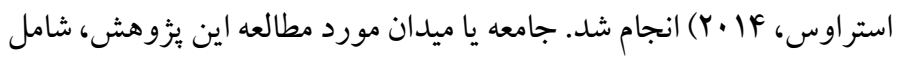

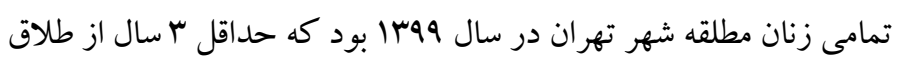

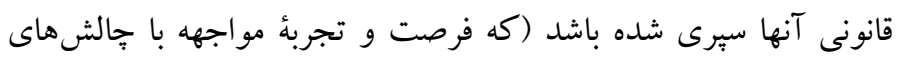

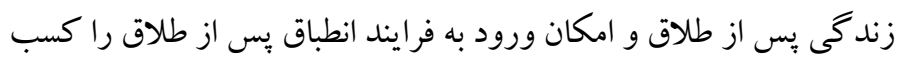

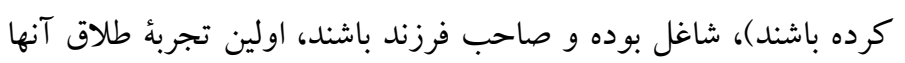

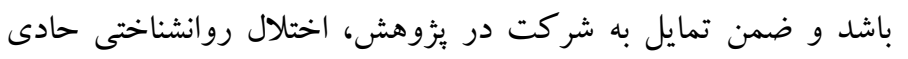

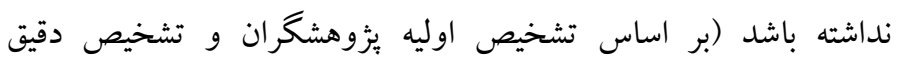
روانشناس بالينى بر اساس مصاحبه بالينى و آزمونهاى تشخيصى معتبر) و 
جدول ا. مشخصات اوليةً زنان مطلقه شر كت كننده در يُوهش

\begin{tabular}{|c|c|c|c|c|c|c|}
\hline تعداد فرزند & 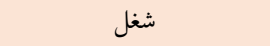 & تحصيلات & علت طلاق & سابقه طلاق & 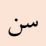 & كد - ا \\
\hline l (يسر) & منشى يزشك & دييلم & خيانت & F & m & 1 \\
\hline | (دختر) & معلم & ل ليسانس & خشونت فيزيكى & r & rq & r \\
\hline | & حسابدار شر كت خصوصى & 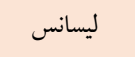 & اعتياد و قاجاق & $\wedge$ & ra & $r$ \\
\hline r (يسر و دختر) & دستفروش مترو & دييلم & اعتياد & $\checkmark$ & fr & r \\
\hline | & مربى مهل كودكى & فوق ليسانس & 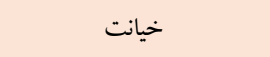 & $v$ & rq & $\Delta$ \\
\hline ا & معلم & ل ل ل ليسانس & مشكلات روانشناختى شوهر & r & rv & 4 \\
\hline Y Y (دختر) & رانده آزانس & فوق دييلم & اعتياد & 4 & Fq & v \\
\hline r (r دختر و ا پيسر) & فروشنده & ديلم & بى مسئوليتى & 19 & $\Delta 1$ & $\wedge$ \\
\hline | & كارمند بانك & ل ل & بيكارى و خيانت & 9 & rr & 9 \\
\hline 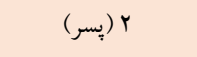 & مربى ورزشى & فوق ليسانس & دخالت خانو اده شوهر & 11 & f. & 1. \\
\hline ا l & كار خر كار كاه جوراببافى & فوق دييلم & اعتياد & 1. & fr & 11 \\
\hline | & كارمند ادارة دولتى & ل ليسانس & اختلاف باورهاى مذهبى & $\Delta$ & rq & ir \\
\hline
\end{tabular}

به كار گرفته است؟ به جز نمونه سؤالات اوليهاى كه در سطور فوق مورد

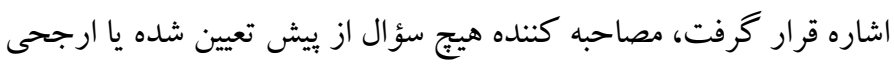

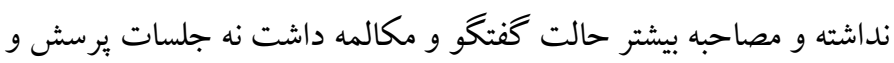

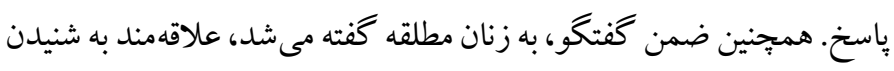
ديد كاهها، دانش و تجارب آنها از موضوع موردنظر هستيم. در مو اقع لزوم جهت عميقتر شدن مصاحبه و براى دستيابى به جزئيات بيشتر، روشنسازى و كسب اطلاعات دقيقتر، سؤالات كاوشى مانند "مىتوانيد در اين مورد

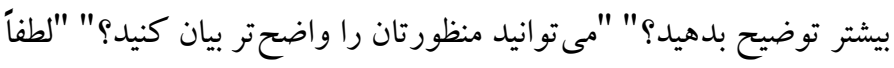

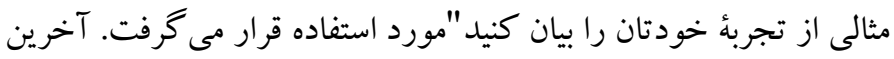

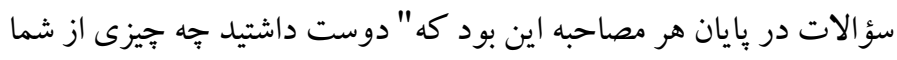

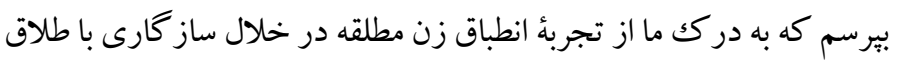

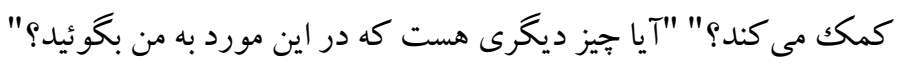

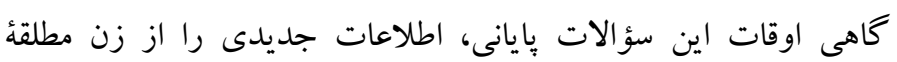

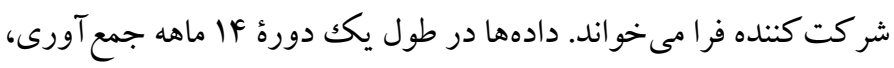
ثبت، كُددگذارى و در قالب مقولههاى اصلى، فرعى و كُدهاى اوليه (باز)

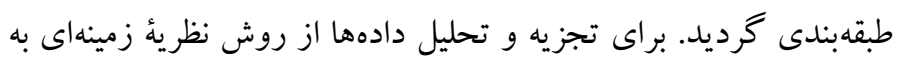

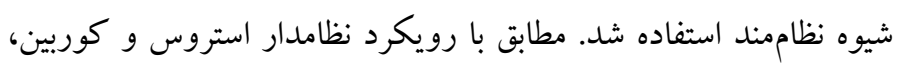
طى فر آيندى منظم و درعين حال مداوم از مقايسه دادهها، اطلاعات مورد

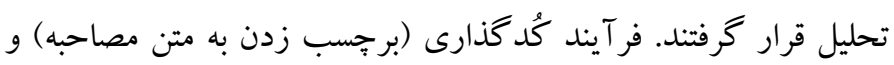

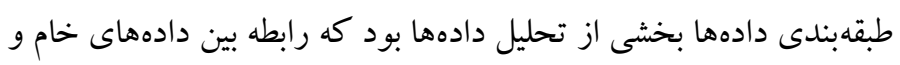

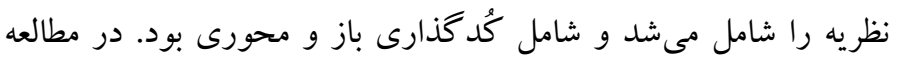

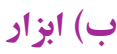
در اين يزوهش بر إى جمع آورى دادهها، از مصاحبة عميق نيمه ساختاريافته

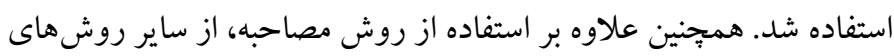
جمع آورى اطلاعات در مطالعات كيفى نظير يادداشت بردارى ميدانى و مشاهده نيز استفاده شد (يادداشت مشاهدات مستقيم همه جزئيات و

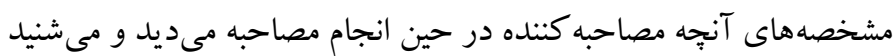

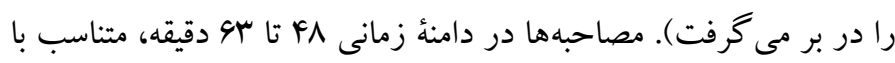

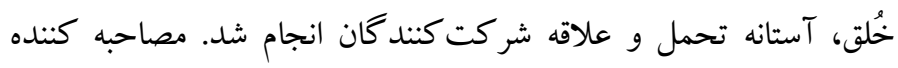

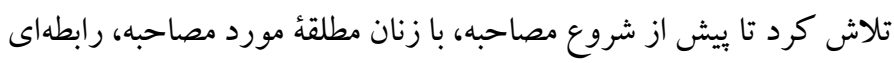

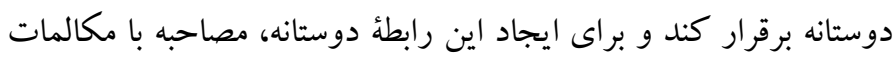

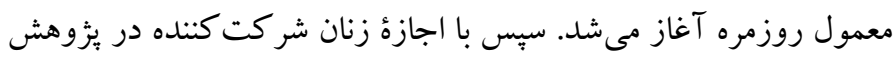

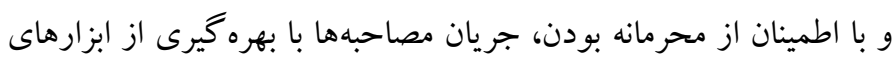

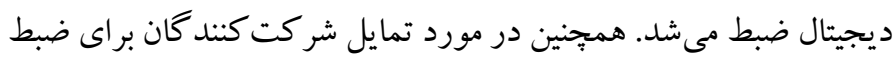

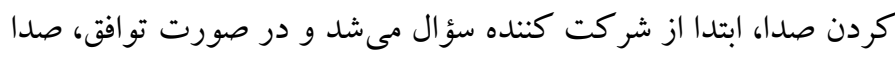
ضبط شده، در غير اين صورت به يادداشت بردارى باسخها اكتفا مى شد. سؤ الات مطالعهُ حاضر به سبب ماهيت روش يثزوهش (روش نظريه زمينهاى)

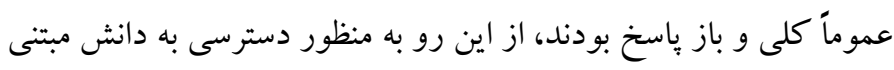

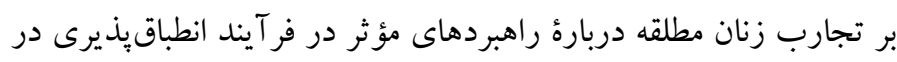

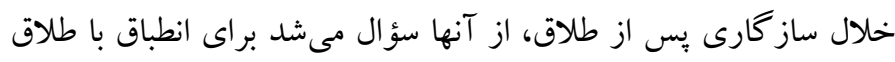

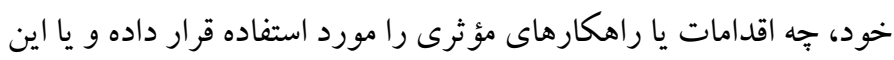

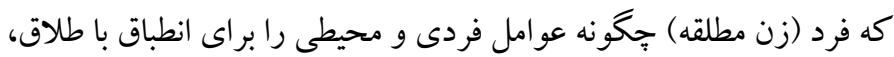


r. استفاده از تكنيكك مميزى: در اين تكنيك از سه متخصص در حوزه

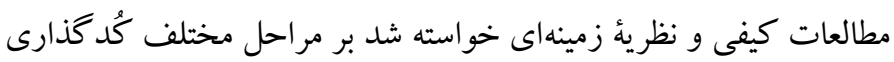

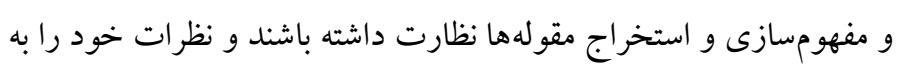

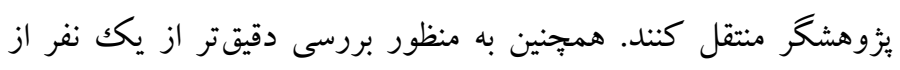

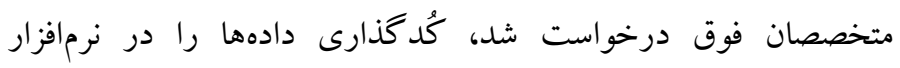

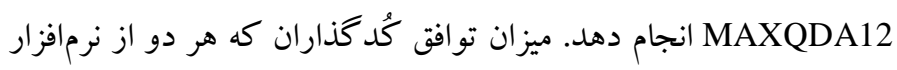
نام برده استفاده نمودند، مناسب، قابل توجه و تضمين كنندهُ ديكرى براى نشان دادن اطمينان و كفايت دادهها بود ( •A/ز).

\section{يافته ها}

منظور از راهبردهاى مؤثر در فر آيند انطباقيذيرى زنان مطلقه، كنشهاى

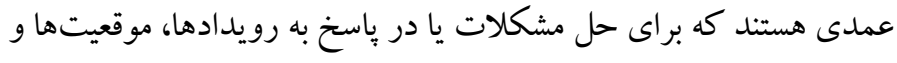

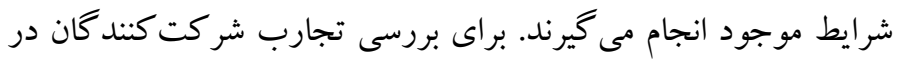
سؤال اساسى بثزوهش، دادههاى حاصل از مصاحبه هاى نيمه ساختاريافته با

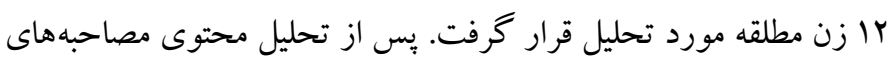

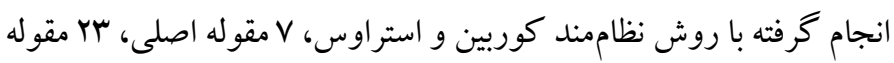
فرعى و ... أ كد باز (اوليه) از تجارب آنان استخر اج شد. راهبردهاى مؤثر استخراج شده در فر آيند انطباقيذيرى زنان مطلقه در مطالعهُ حاضر شامل

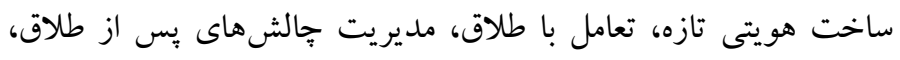
درگير شدن در فعاليتهاى اجتماعى (تأثيرات محيطى)، ضربه گيرها

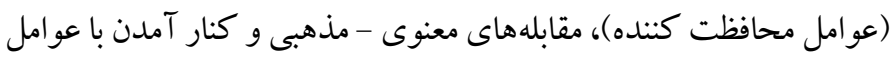

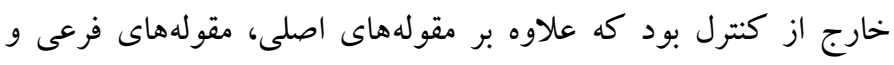
كدهاى باز (اوليه) آن نيز در جدول بود به آمده است.
حاضر يّ از يِادهازى مصاحبها در قالب متون و تحليل سطر به سطر

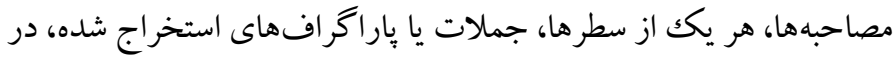

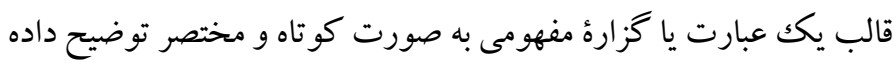

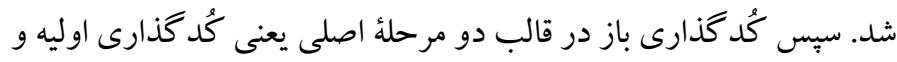
كُدگذارى متمركز (مقولههاى فرعى و اصلى) انجام شد. در مر مرحله

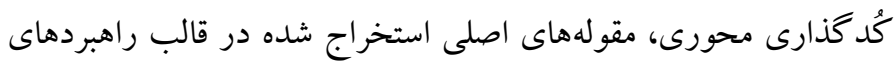

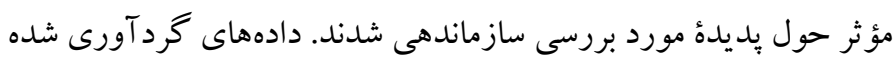

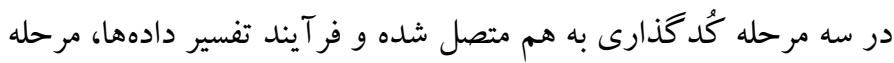
به مرحله از سطح دادههاى خام به سطح مفاهيم انتزاعى و در نهايت رسيدن مدرن

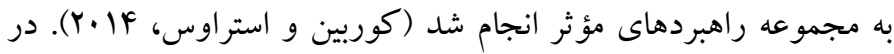
روش نظريه زمينهاى از سه شيوه براى نامگذارى مقولات استفاده مى مودد؛

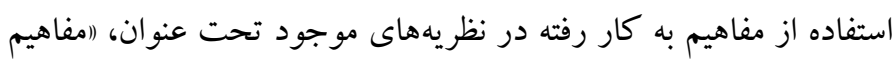

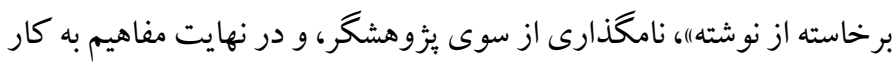

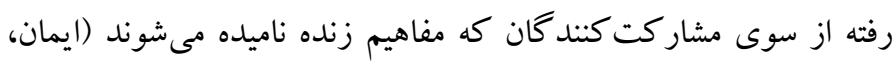
مشNVV

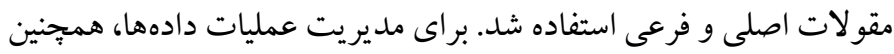

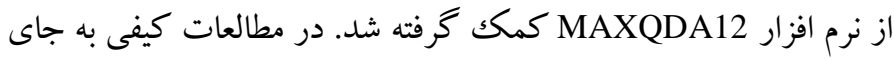

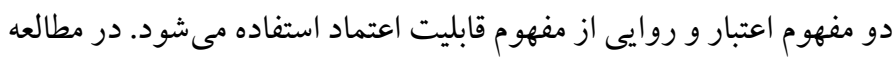

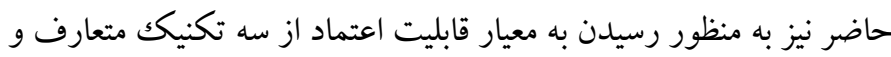

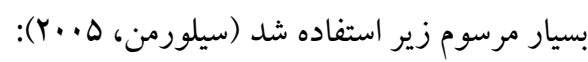

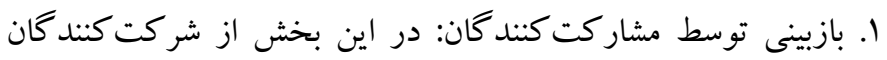

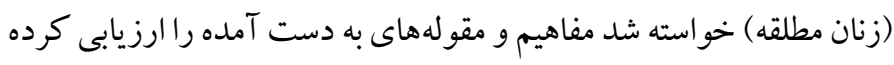
و درباره صحت آن نظر دهند تا وجه اطمينانيذيرى اعتبار كيفى تأمين شود. براى اين منظور يس از تحليل هر مصاحبه، متن مصاحبه دوباره به شر كت

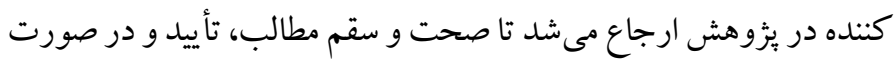

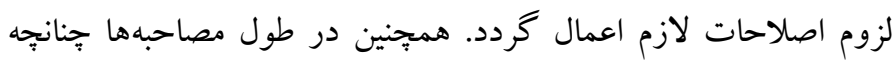

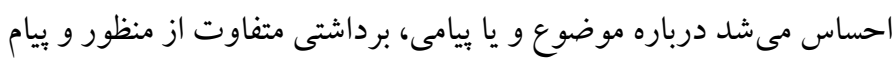

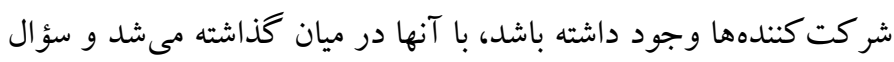
مى شد كه آيا تفسيرى كه از ييامها برداشت شده، صحيح است يا نه.

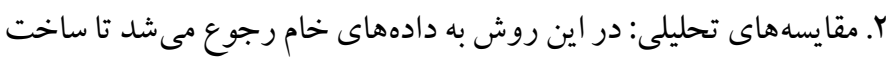
بندى مقوله هاى مستخرج با دادههاى خام مقايسه و ارزيابى شود. 
جدول r. مقوله هاى مرتبط با راهبردهاى مؤثر در فر آيند انطباقيذيرى در خلال ساز كارى يّ از طلاق

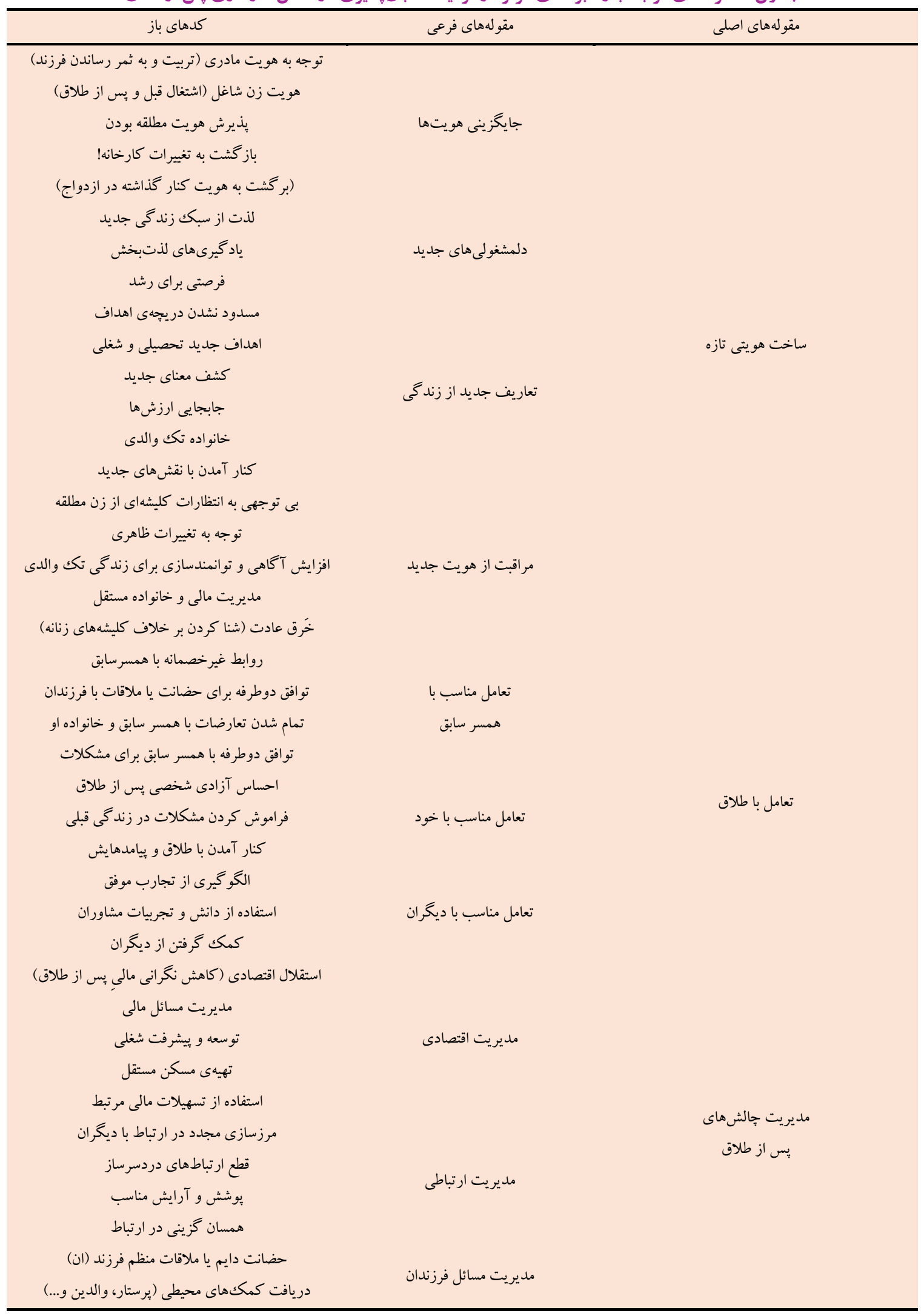




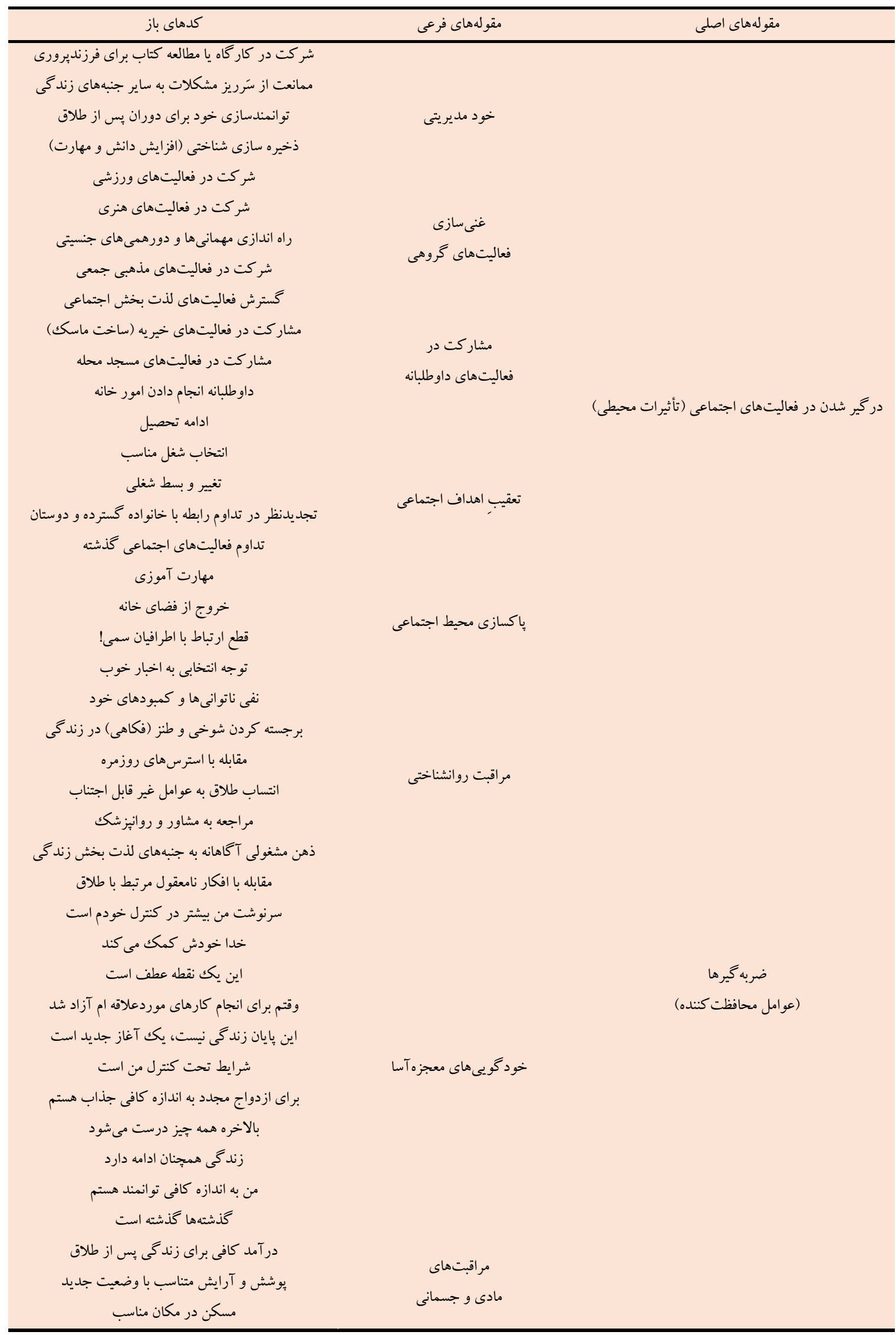




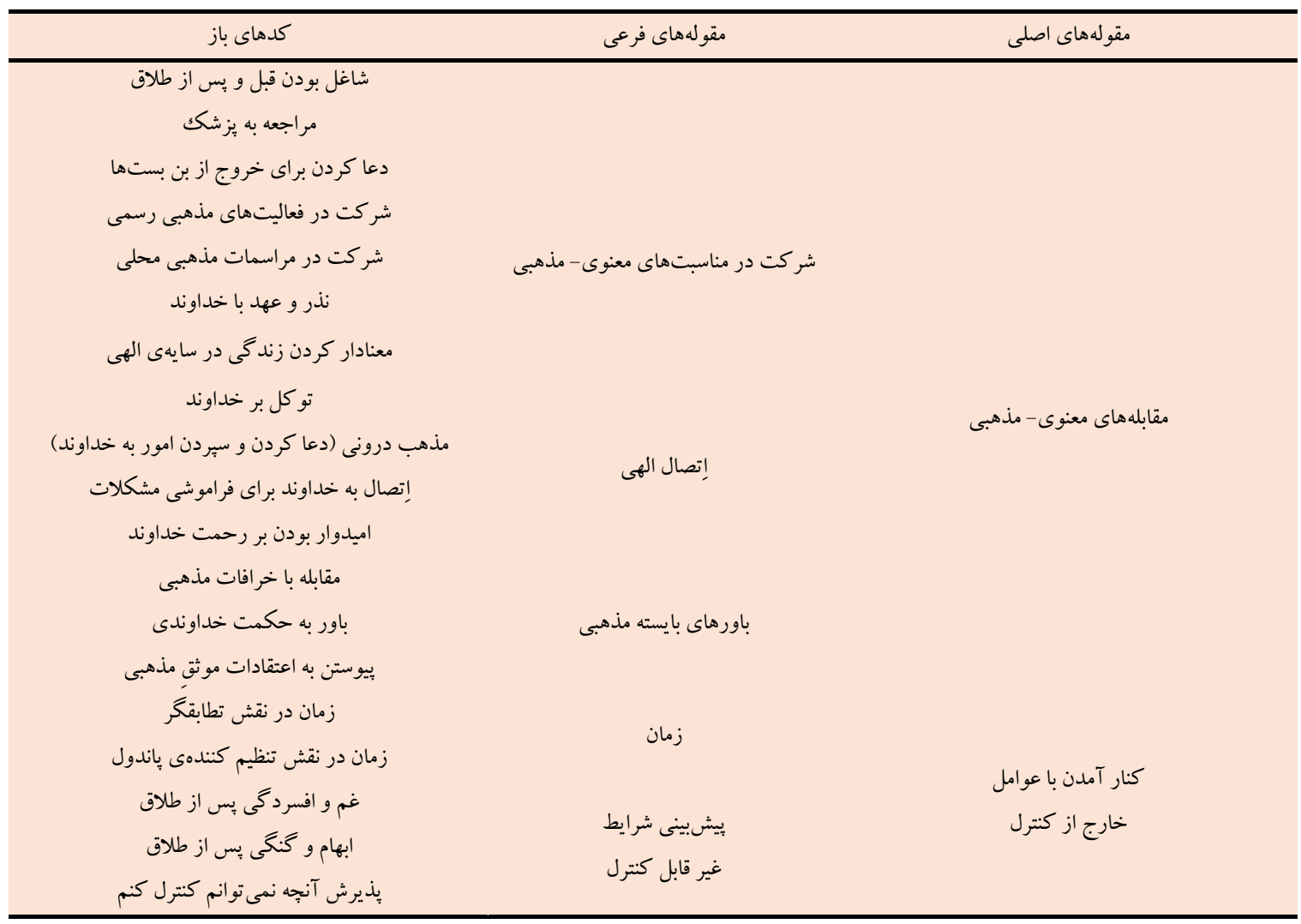

روند باز تعريف (اخود) و ساخت هويتى تازه را "يذيرش هويت مطلقه

مقوله اصلى ا: ساخت هويتى ثازه

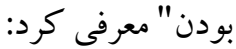

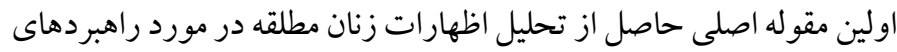
"ايايد اينو قبول كنى كه ديكه تنها شدى، شوهرت نيست و همد كاراتو مؤثر در فر آيند انطباق يذيرى با طلاق، ساخت هويتى تازه بود كه فر آيند

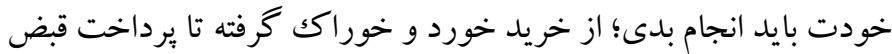

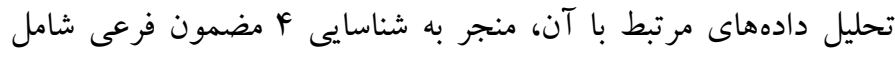
و كارهاى ادارى و بقيه كارات ... تا قبول نكنى كه ديگه كسى كنارت

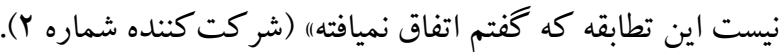

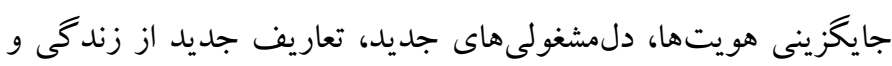
شركت كننده ديخرى "بذيرش وضعيت خانو اده تكك والدى" را را به عنوان

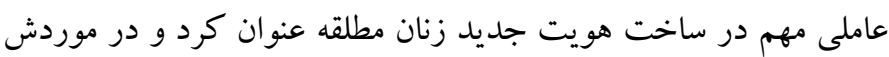
كفت:

(بالاخره آدم بايد قبول كنه اين وضعيت رو كه ديگه خودشه و خودش كا (مكث مى كند) بايد تكى همه جى رو مديريت كنه. البته يه خوبيشم اينه كه

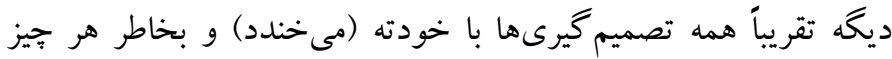
كو جيك و بى ارزشى با يه كسى كه زند

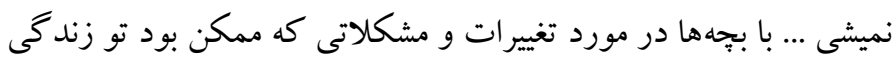
بعدى مون [زندگى تكك والدى] به وجود بياد صحبت كردم. البته خدا رو لهو

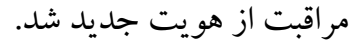
همانطور كه افراد با ازدواج، هويت جديد زن و شوهرى مىيابند، با طلاق

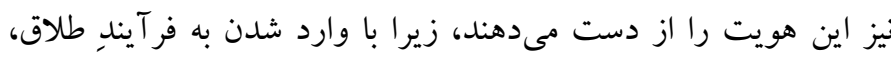

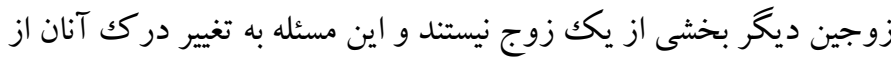
(اخو د) منجر مى شود. تغييرى كه مى تواند به نوعى ابهام نقشى و تصور مبهم

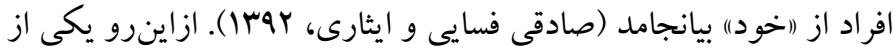
جالشهاى اساسى كه زوجين بس از طلاق با آن مواجه مىشوند، لزوم باز

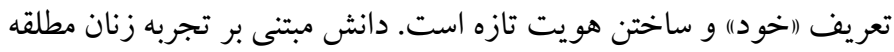

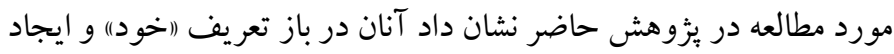
ساختار هويتى منطبق بر وضعيت جديد به راهكارهاى جديدى دست بيدا

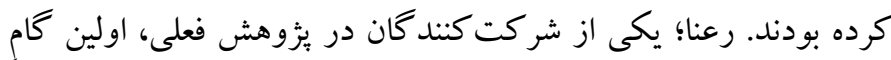


ما [من و شوهرم] از همون روزاى اول اختلاف و قبلِ طلاق توافق كرديم

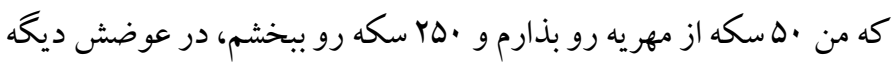

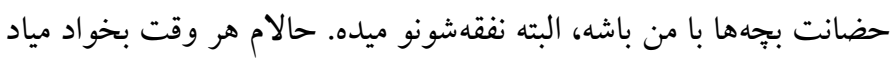

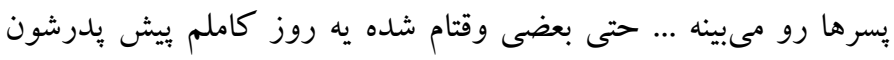

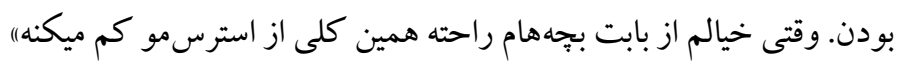

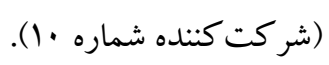

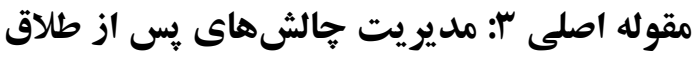

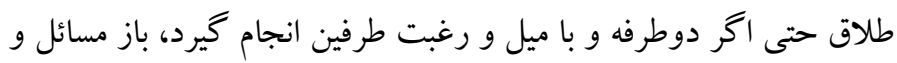

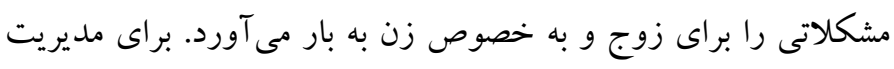

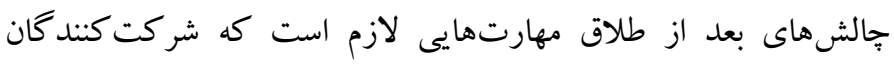
يزوهش حاضر در قالب مقولات فرعى شامل مديريت اقتصادى، مديريت

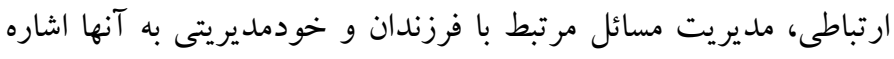

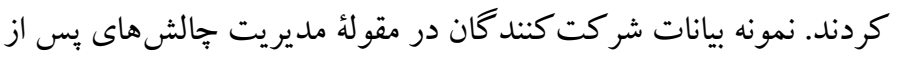
طلاق در سطور ذيل ذكر شده است: مديريت اقتصادى: (اطلاق كه گَرفتم همه فكر مى كردن با سَر ميخورم زمين

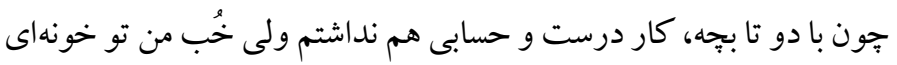

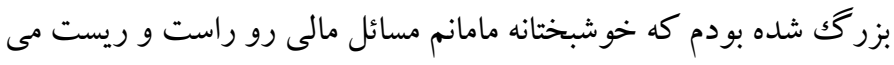

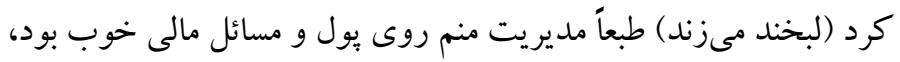

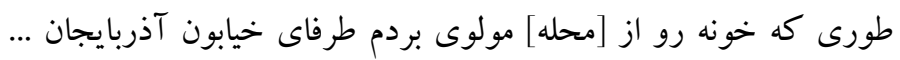
جديداً ميخوام يه دستگاه ميوه خشك كن سفارش بدم كنار كار باشگاه

$$
\text { اونم بشه يه منبع در آمدى ...1) (شر كت كننده شماره . . (1). }
$$

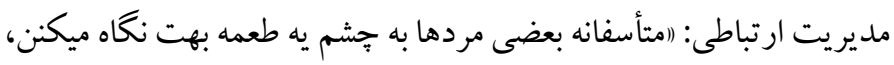

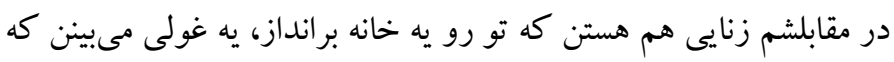
هر لحظه ممكنه شوهرشونو بدزدى، هر قدرم كه بكى نخاهشون بَده، منفيه، بى فايده است ... قطع رابطه با اينجور آدماى دردسرساز، خيلى كمكم كردها

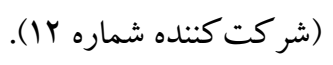

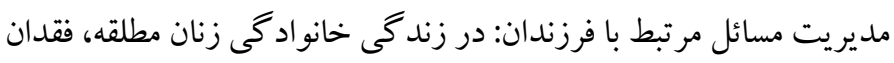

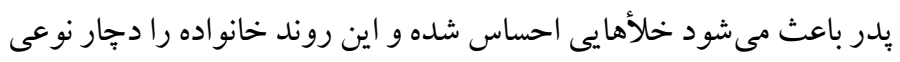
نقصان مى كند. در اين شرايط، مادر بايد بتواند نقش دو كانه خود (مادر و و

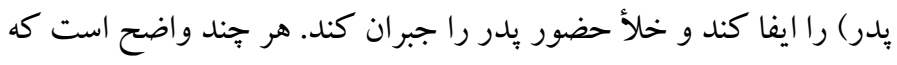

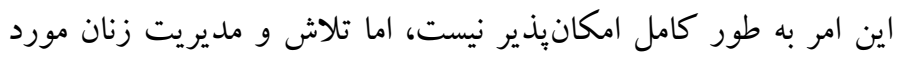
مطالعه در اين زمينه، قابل تأمل و تأثير گذار بود:
شكر بجههاى من دختر بودن و از اين نظر خيلى صدمه نديدن) (شركت

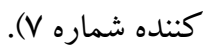
تطابق وضعيت ظاهرى زن با شرايط جديد نيز نشان دهندهُ تلاش وى براى

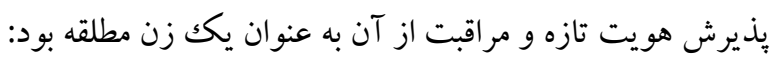

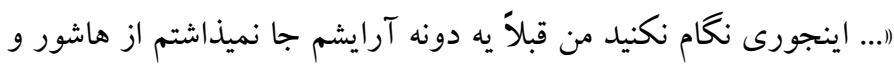

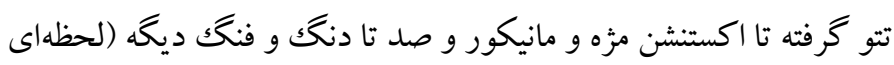
مكث مى كند، دستهايش را روى صورتش كذاشته و فشار مىدهد) اوائل طلاقم باز شور [غليظ] آرايش مى كردم ولى كم كم فهميدم بايد يه كم روى صورنش رعايت كنم اكه ميخوام خودم كمتر اذيت بشم ... نه اينكه ديخه اصلاً

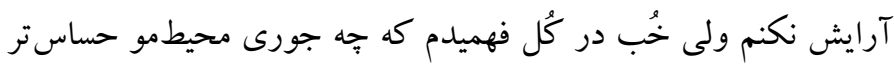

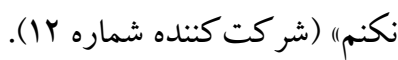

\section{مقوله اصلى r : تعامل با طلاق}

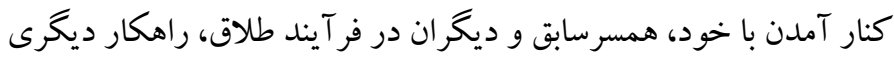

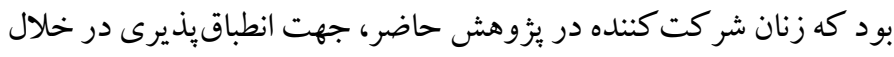

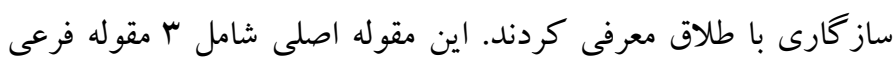

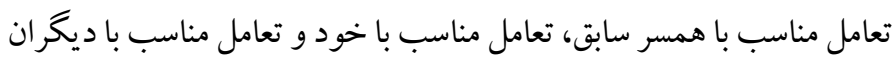

يكى از شركت كنند كان كه روابط غير خصمانه با همسر سابق در جريان طلاق رادر اين فر آيند، راهگشا تشخيص داده بود در اين زمينه گفت كان

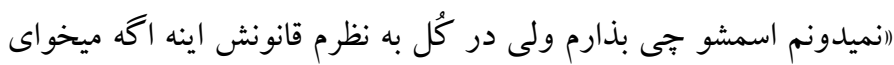
زندگى كنى خوب زندگى كن وگرنه خوب جدا شو ... دعوا و جنجال و

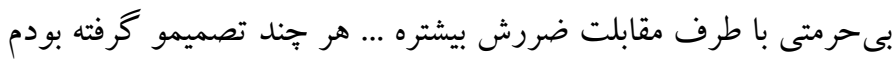

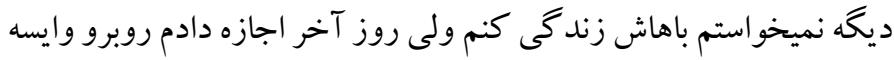
حرفاشو بزنه و بى احتر امى هم به همديگه نكرديم ...) (شر كت كننده شماره

زن مطلقه ديخرى، توافق با شوهر سابقش روى مسائل مختلف زندكى به خصوص فرزندان را راهكار مؤثرى در تطابق با طلاق معرفى كرد:

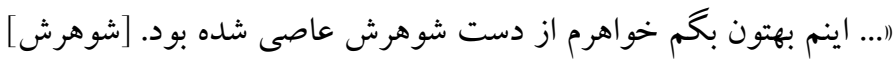
هر روز خدا ميومد جلوى خونه بابام داد و بيداد كه مردم اينا بجِهمو بردن سترن فردا خرابكارش مى كنن، فاسدش ميكنن اينا سه دخترشون طلاق گرفته ...

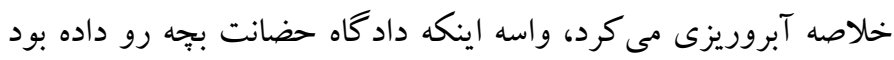

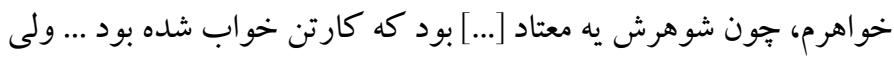


اجتماعى، حر كت شان به سمت انطباق و سبس ساز كارى را تسهيل مى كرد.

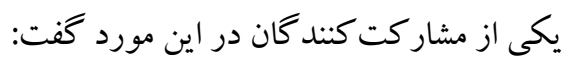

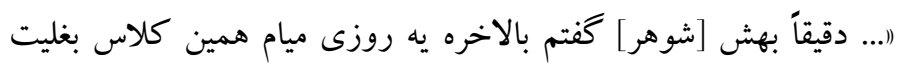

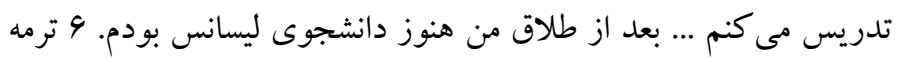
ليسانس گرفتم و با سهمئ دانشجوى ممتاز رفتم فوق ليسانس و اونم

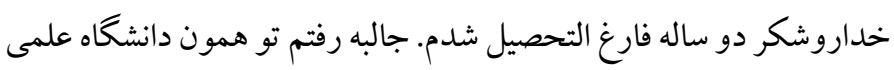
كاربردى كه شوهر سابقم تدريس مى كرد، بهم درس دادن ... وقتى متوجه

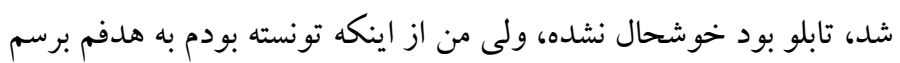

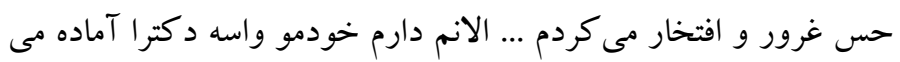

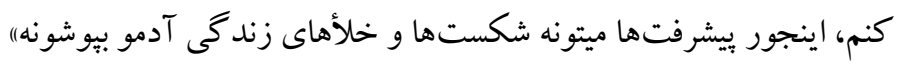

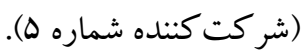
همجنين انتخاب شغل مناسب با وضعيت زن مطلقه نيز راهبرد مناسبى براى دنبال كردن اهداف اجتماعى بود: (.... اونجايى كه ما مىنشستيم [محل سكونت] ديدشون نسبت به آرايشخر مطلقه منفى بود ... قبلش خيلى ديده بودم كه وقتى مىفهميدن زنه مطلقه

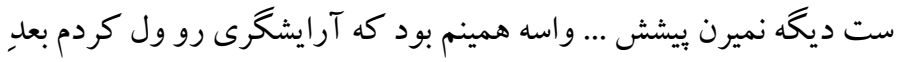

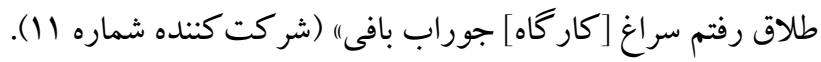

\section{مقوله اصلى 0: ضربه كيرها (عوامل محافظت كننده)}

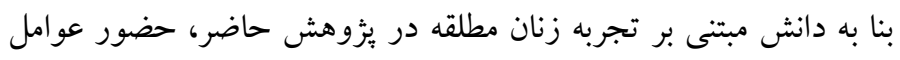

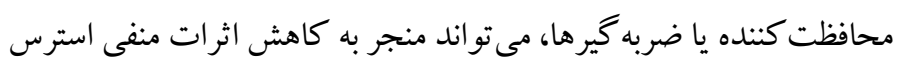
ناشى از جدايى و طلاق شود. گاهى اين عوامل محافظت كننده به عنوان راهكارى مفيد، مى تواند حتى منابع لازم را براى حل مشكلات فر فراهم آورد.

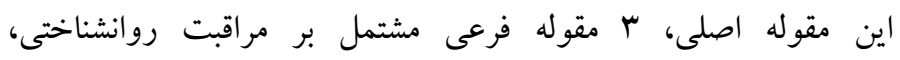

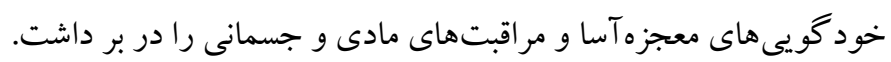

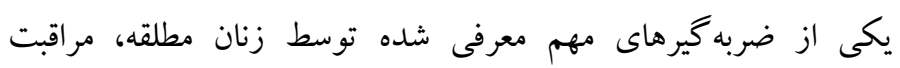

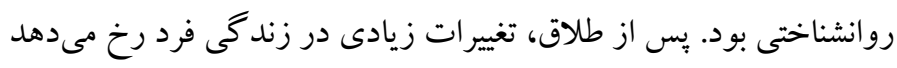
كه ضرورت خودمراقبتى به خصوص مراقبت روانى بيش از ييش اهميت

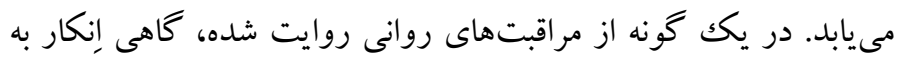

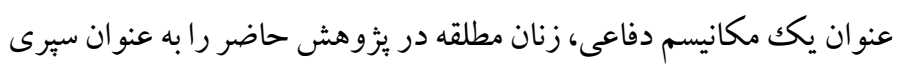

$$
\text { از لبهُ تيز اضطراب دور مى كرد: }
$$

(1... از همون موقع طلاق ياد گرفتم اگهه ميخوام زودتر از اين شرايط خارج

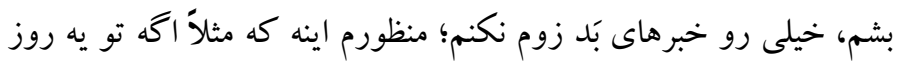

"اهر جيم كه مشغله داشته باشم براشون [فرزندان] وقت ميذارم ... باور مى

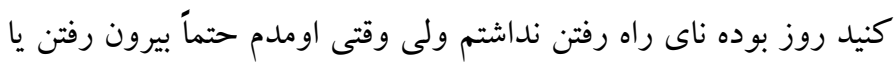

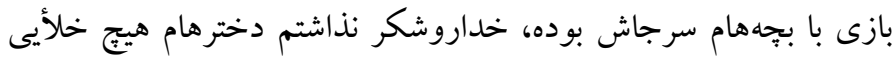

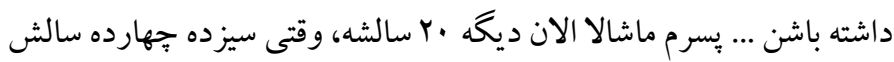

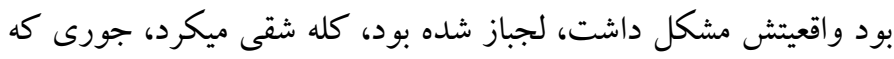

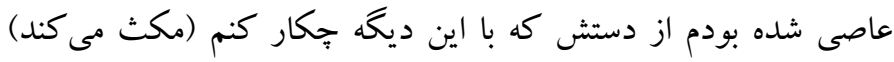

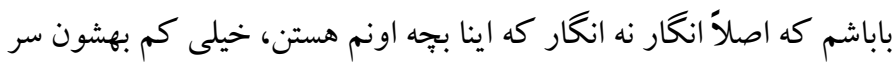

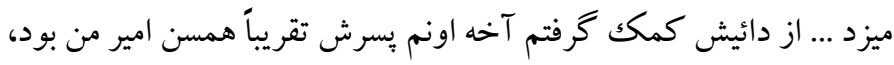

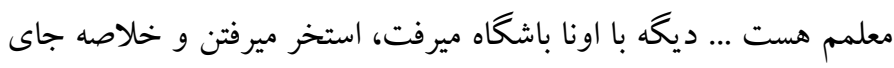
يدر كه بُر نميشه ولى اوضاعش خيلى بهتر شد ...1) (شر كت كننده شماره A).

\section{مقوله اصلى ع: دركير شدن در فعاليتهاى اجتماعى}

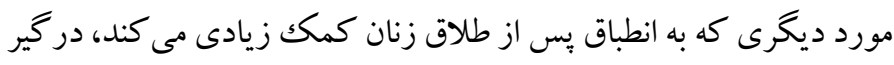
شدن در فعاليتهاى اجتماعى است. دانش مبتى بر تجربه زنان مطلقه در

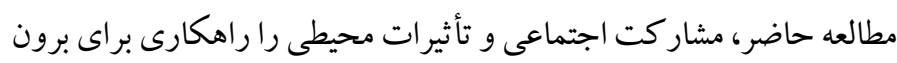
رفت از مشكلات پِ از طلاق و انطباق با آن معرفى كرد. اين مقوله اصلى

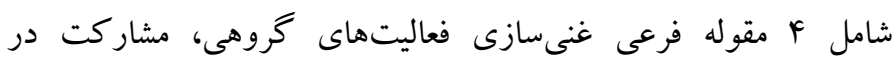

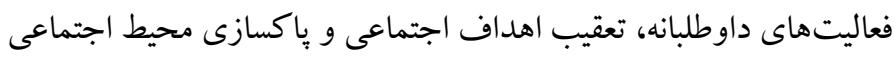

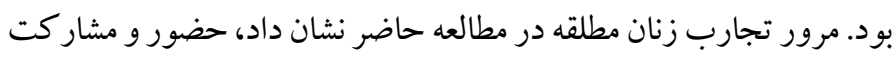

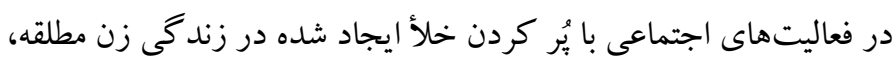
زمينه را براى انطباق بيرونى او فراهم مى سازد.

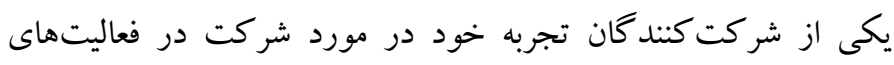

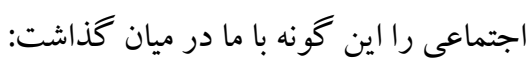

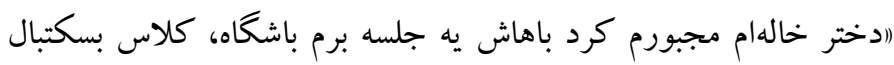

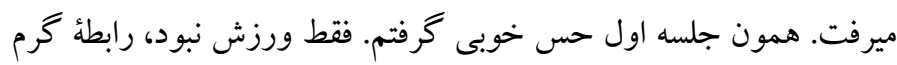

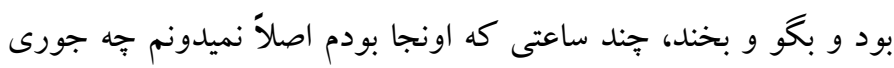

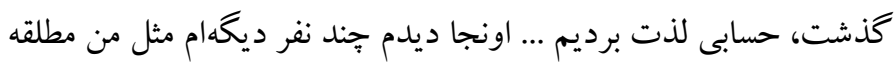

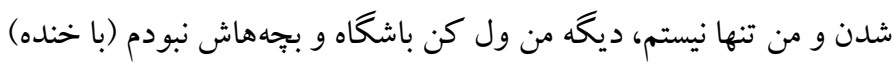

الان صميمى ترين دوستام از بين هموناست) (شركت كنتده شماره بـ (1).

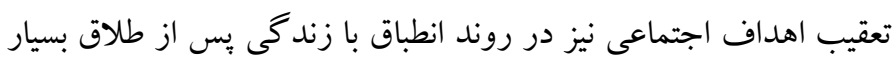

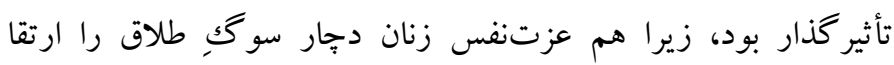
مىبخشيد و هم با مشغول كردن و مشاركت آنان در فعاليتهاى متعدد 
(بايد باور كرد بعضى وقتا طلاق شروع زندگى تازه و شروع دوباره و رسيدن

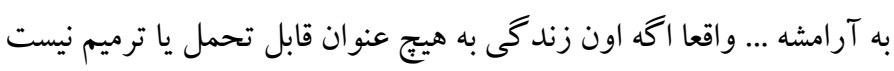
نبايد از جدايى ترسيد ... من هميشه ورد زبونم بود كه اين يه شروع دوباره ست ...) (شر كت كننده شماره ه). طلاق، تجربه ناخوشايندى است كه علاوه بر عوارض روانى و اجتماعى، از از

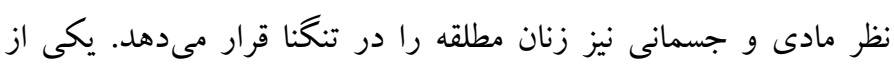

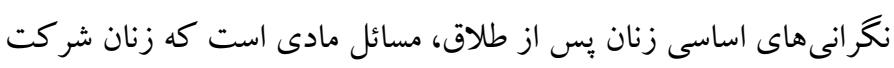

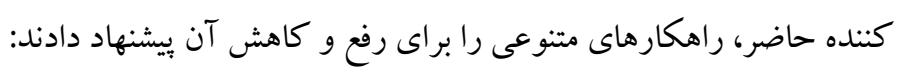

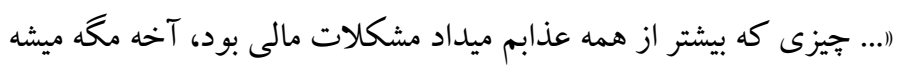

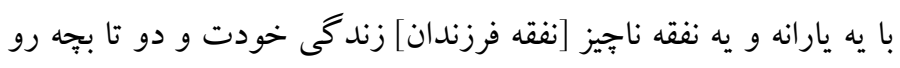

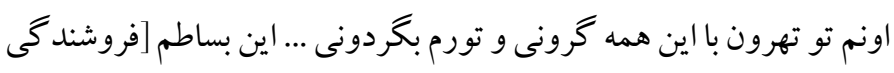

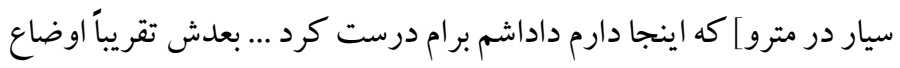

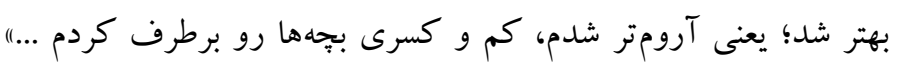

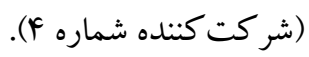
داشتن مسكن مناسب هم دغدغههاى زنانه پِس از طلاق را بيشتر مى كاهد:

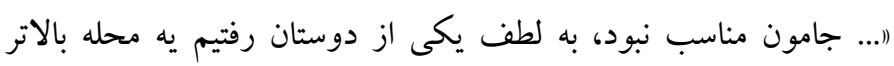
واحدى گرفتم كه تقريباً اغلب ساكنينش مثل خودم مطلقه بودن ... نميدونيد

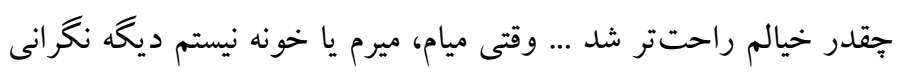
ندارم. تو اين جور زند گيا هر جايى نميشه نشست) (شر كت كننده شماره V).

\section{مقوله اصلى 7: مقابله هاى معنوى - مذهبى}

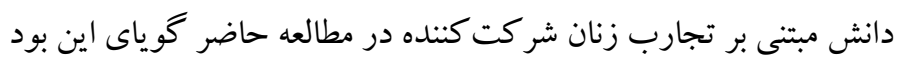

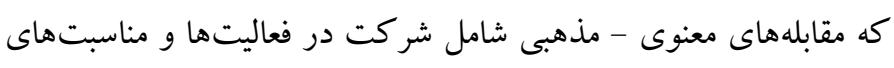
معنوى - مذهبى (دعا كردن براى خروج از بن بستها، شركت دمان درى فعاليت هاى مذهبى رسمى، شر كت در مراسمات مذهبى محلى، نذر و عهد

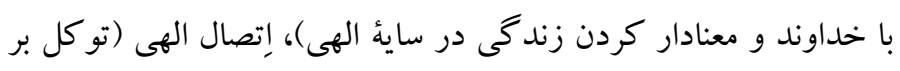

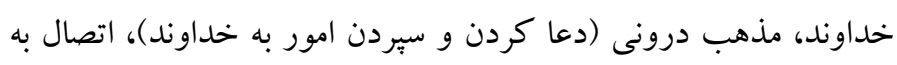

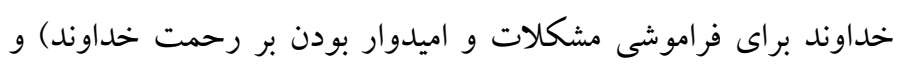

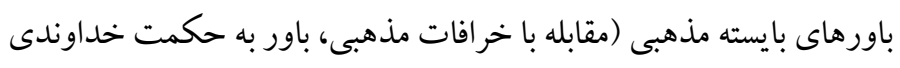

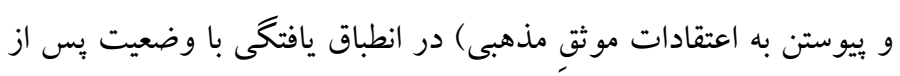

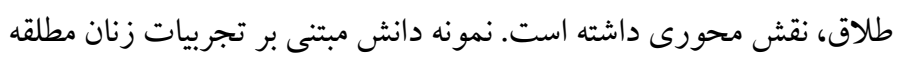
در زمينه مقابلههاى معنوى - مذهبى در سطور زير آمده است:
بر كه حضانت بجهمو با مثلاً بخشش مهريه رو بهم ابلاغ مى كردن، بيشتر

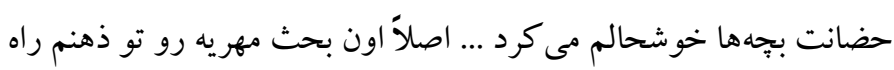

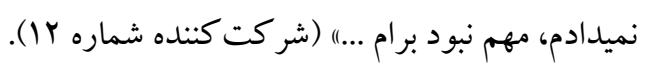

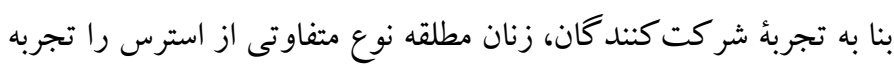

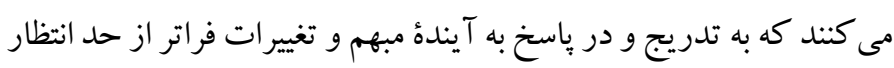

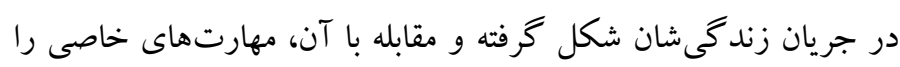
مى طلبد:

"اواقعيتش اينه كه اول كار [اوائل زندگى بَس از طلاق] بدجورى خودمو

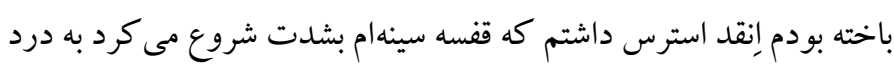
كردن، همة فكر و ذكرم فقط اين بود كه بالاخره كى اين بلاتكليفى تموم

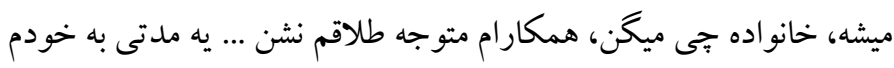

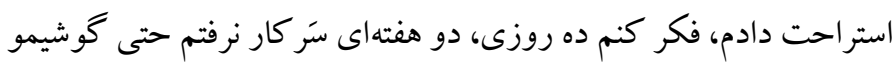

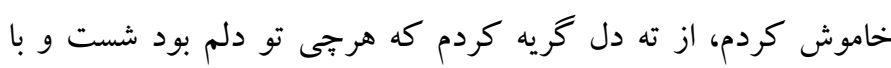

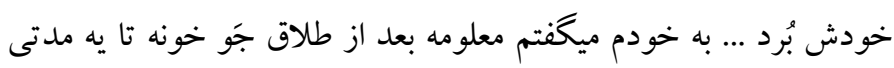

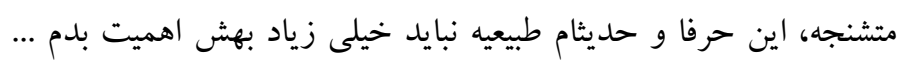

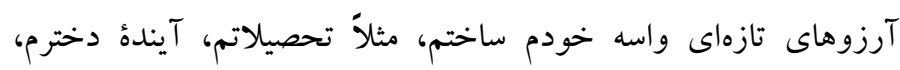
مسافرت خارج از كشور كه جزو آرزوهام بوده هميشه ... جون از نظر ماليم مستقل بودم ترسم از آينده هم كم كم ريخت) (شر كت كننده شماره س).

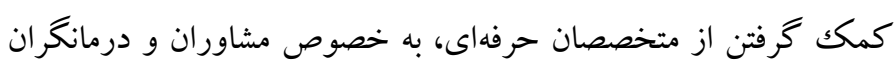
خانو اده نيز به عنوان راهكارى مؤثر براى مر اقبت روانى اروائه شد:

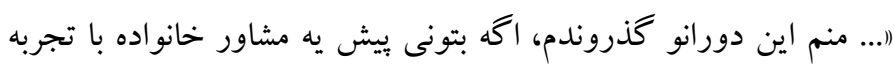

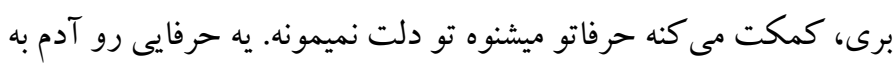

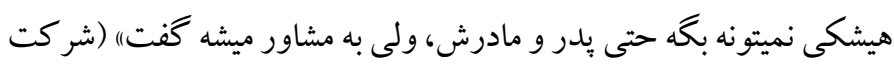

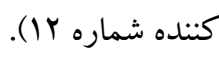
ييامهاى مثبت يا شعارهاى معجزه آسايى كه زنان مطلقه يس از طلاق به به خود مخابره مى كردند، ضربه گير ديخرى بود كه زنان مورد مطالعه را در مقابل

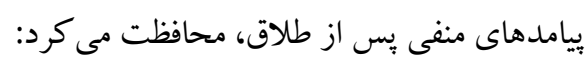

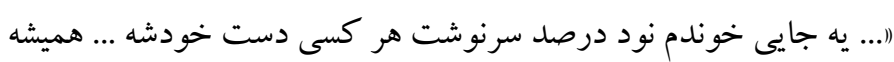

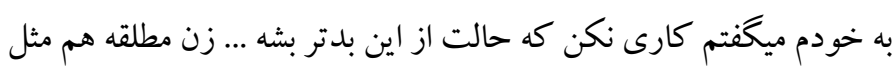
زن متأهل هم روزهاى خوب داره و هم روزهاى بدل) (شر كت كننده شماره 
بيشترى بر قشر زنان وارد كرده و رسيدن آنها را به انطباقيذيرى و در نهايت

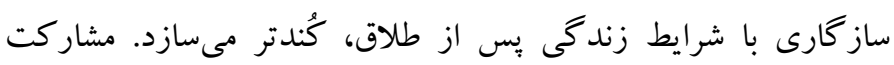

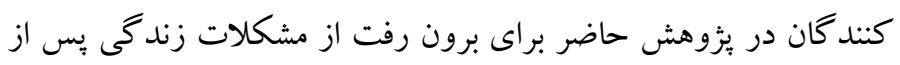

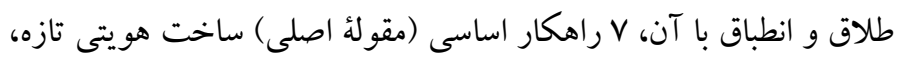

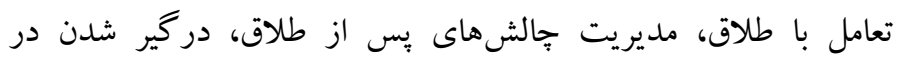

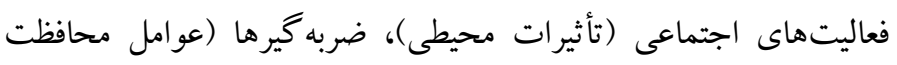

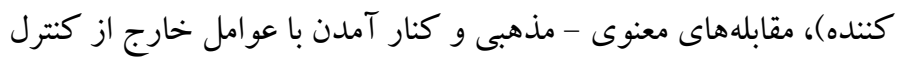
را از دانش مبتنى بر تجارب خويش روايت كردند كه مىتواند روند

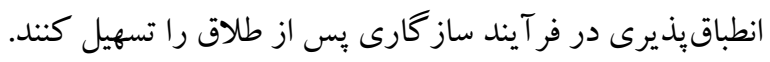

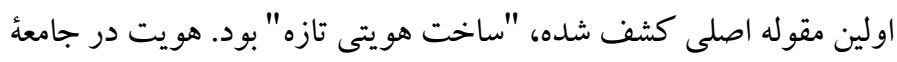
ايرانى به ميزان زيادى با خانواده بيوند دارد؛ بنابراين با شكستن كانون

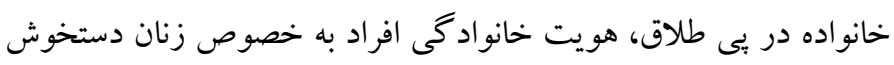

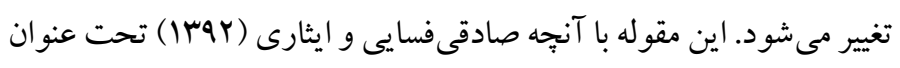
(اباز تعريف خود و ساخت هويت در ميان زنان بِ از طلاق) شناسايى كرده

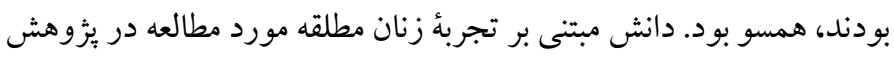

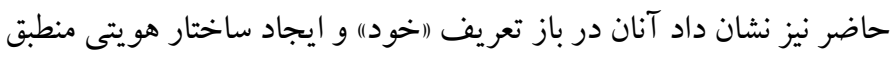
بر زندگى پِ از طلاق به راهكارهاى جديدى دست دست بيدا كرده بودند.

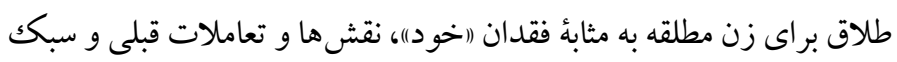

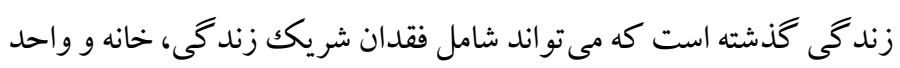

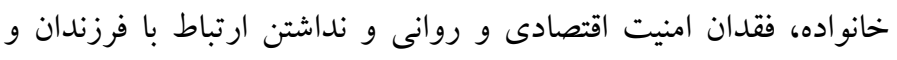

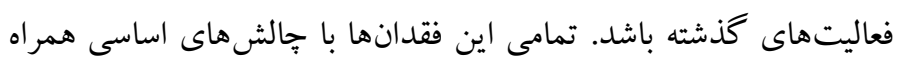

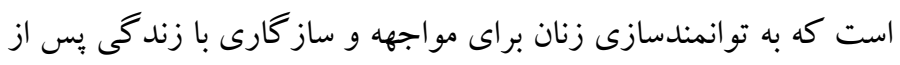

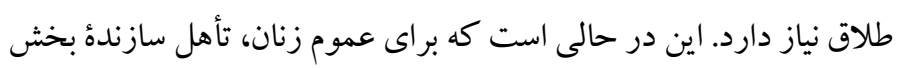

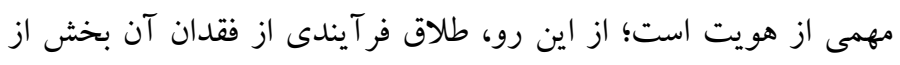

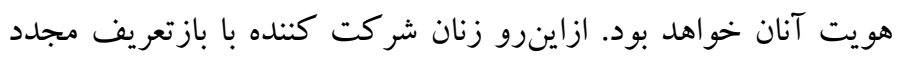
(اخود) بِ إز طلاق توانسته بودند، هويت جديدى خلق كرده كه آنها را

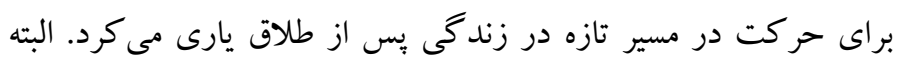

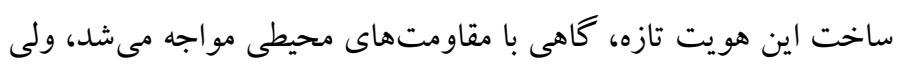
يذيرش درونى از طرف زن مطلقه و تعامل مناسب او با جهان بيرونى، اين

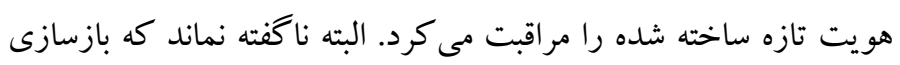
مجدد در اين زمينه و ساخت هويت جديد براى زنانى كه با عامليت خود

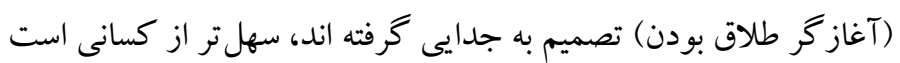

(.... حال و روز خوشى نداشتم با اصرار دوستام بود كه رفتم ييادهروى اربعين ... واسه ترميم زخماى روحى و روانيم رفتم سمت امام حسين [عليه السلام]

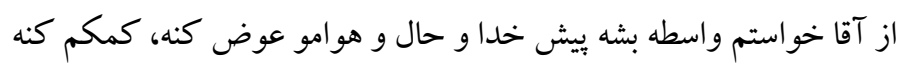

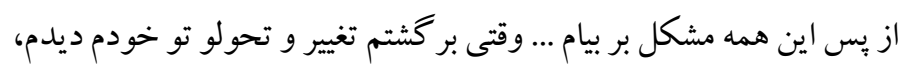

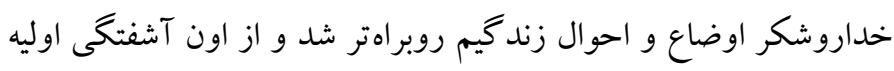
خلاص شدم ...1) (شر كت كننده شماره F). (اهميشه اميدوارم بودم به رحمت خودش [خداوند] ولى متأسفانه مادرم

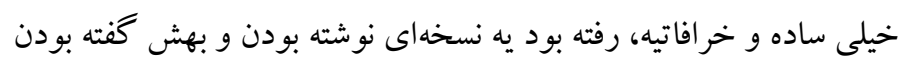

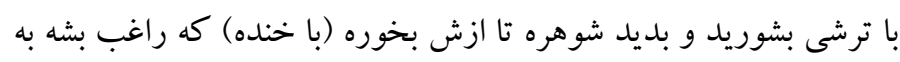

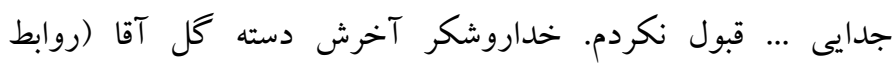
فرازناشويى) افتاد بيرون و بعدش بالاخره خودش راضى شد به طلاق ...

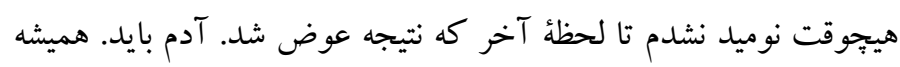

تو كلش به خدا باشه...) (شر كت كننده شماره ()).

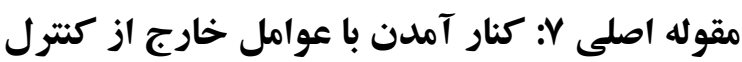

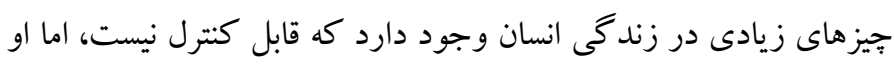

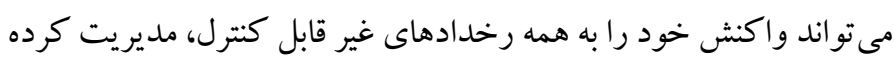

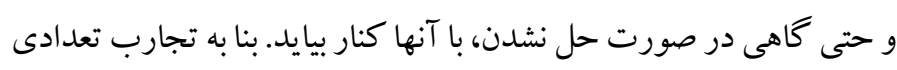

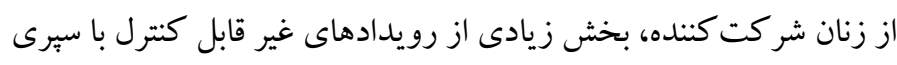
شدن زمان، مديريت شده يا حداقل قابل تحمل تر مى شوند.

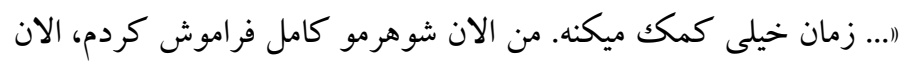
شش ساله ازش جدا شدم. اون اوائل خيلى توى ذهنم ميومد، ياد خوبيا و

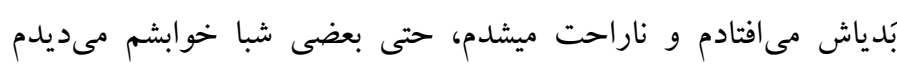

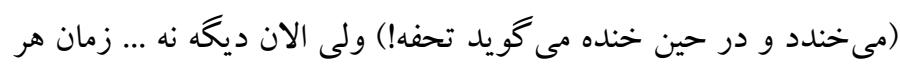

جيزى رو كمرنگك ميكنه)) (شر كت كننده شماره V).

\section{بحث و نتيجه كيرى}

مطالعه حاضر با هدف دستيابى به دانش مبتنى بر تجربهُ زنان مطلقه ازئ

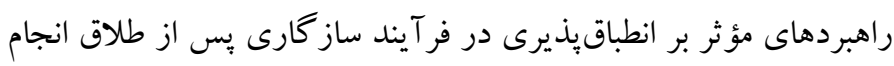

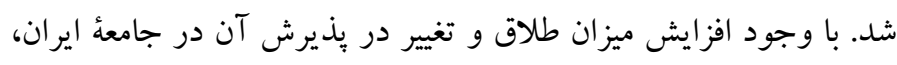

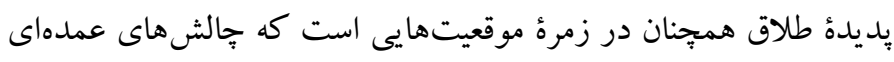
را در ابعاد جسمانى، روانى، اجتماعى و حتى معنوى براى افراد به دنبال

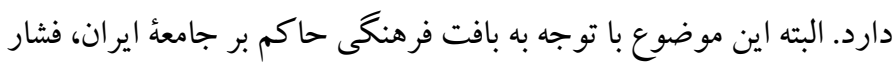


خودمديريتى از جمله خرده مهارتهايى بودند كه زنان مطلقه در مطالعه

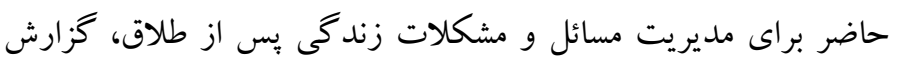

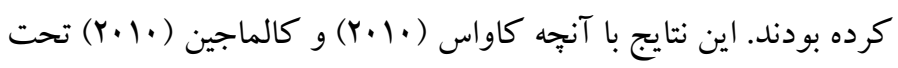
عنوان حل مشكلات اقتصادى و ارتباطى پس از طلاق مطرح كرده بودند،

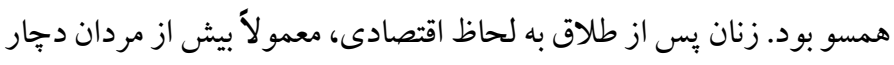

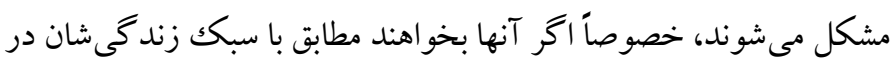

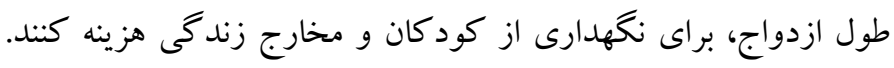

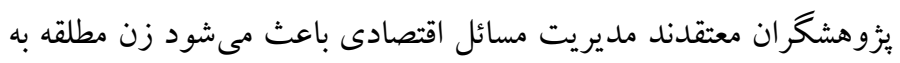

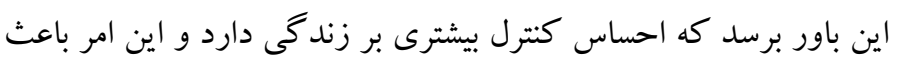

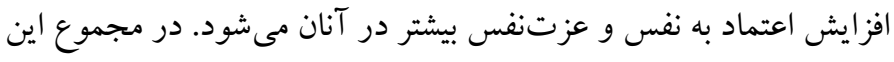

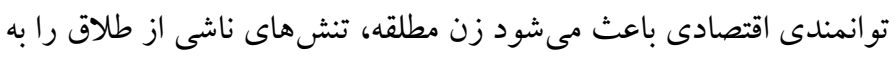
طور مناسبترى مديريت كند (صباغى، صالحى و مقدمزاده، و9Mا).

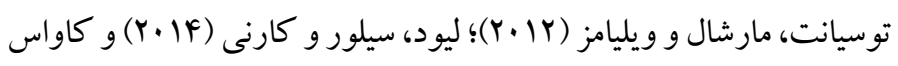

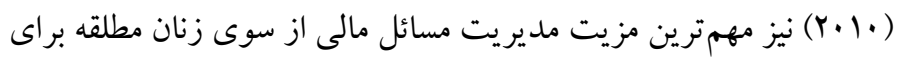

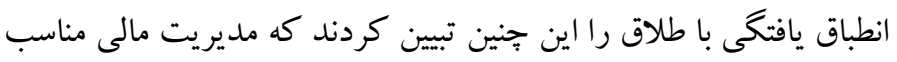

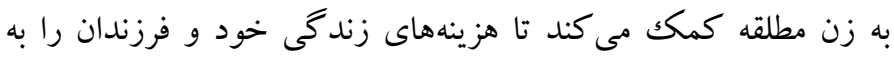
مشكلات روانشناختى ناشى از طلاق اضافه نكند. همجنين داشتن مهارتهاى ارتباطى مناسب در محيط زندگى و كارى، رهايى از تنهايى و

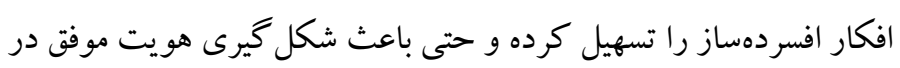
زنان مطلقه مى شود. جهارمين مقوله استخراج شده از راهكارهاى مؤثر بر انطباقيذيرى در

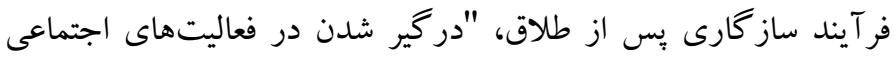

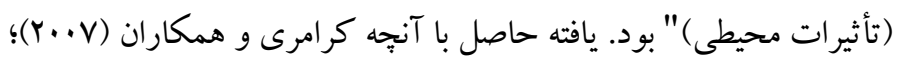

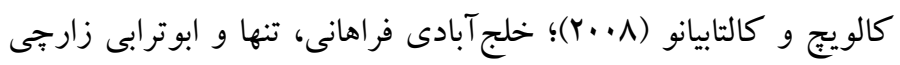

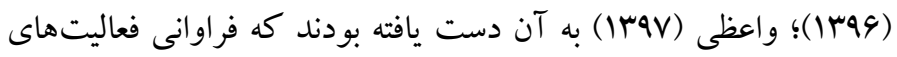
اجتماعى در دوران بس از طلاق با سطح بالاترى از ساز گارى مثبت و سطح

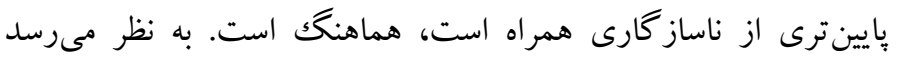

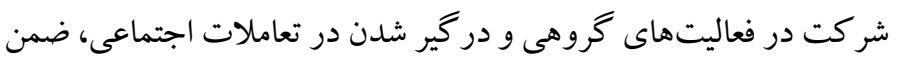
بالايش روانى و تخليه هيجانى زنان مطلقه در يُزوهش حاضر، آنان را در

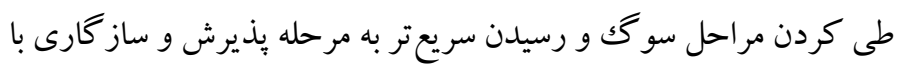

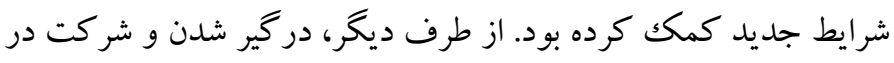

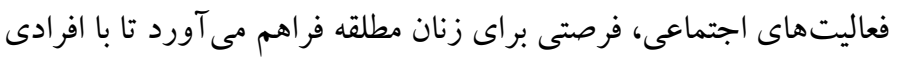

كه با ارادة طرف مقابل يا ساير عوامل بيرونى، مجبور به جدايى شدهاند.

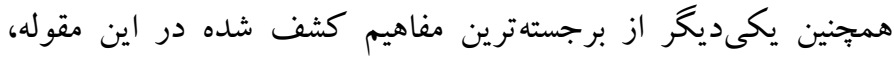

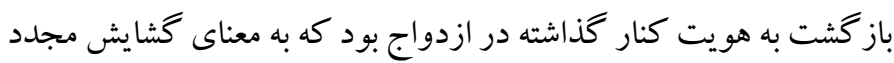
و ساخت مجددى از هويتى قديمى و حل نشدنى زن مطلقه بود كه در طول

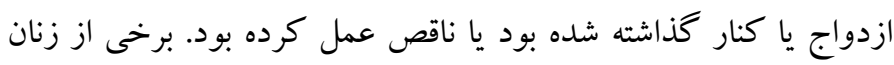

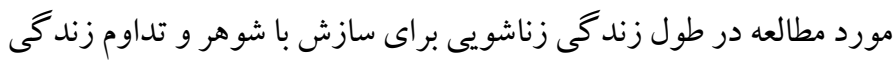

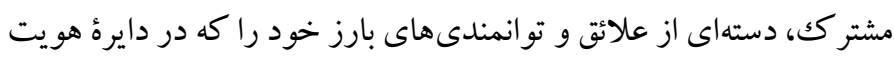

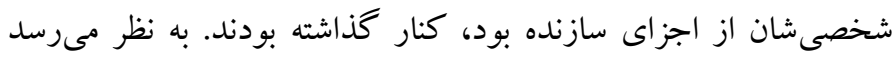

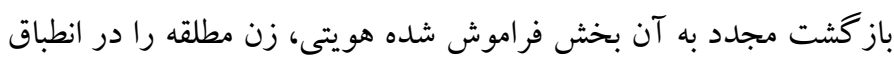

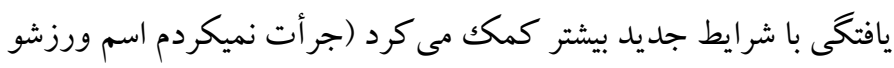

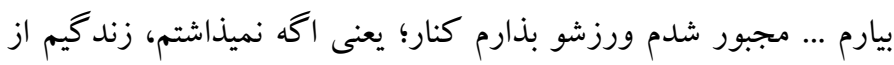

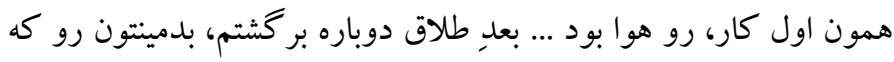

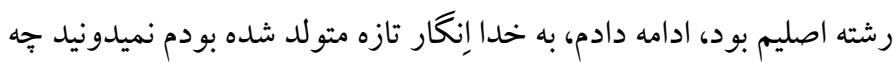

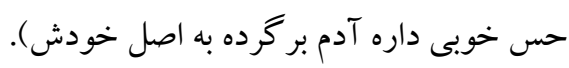

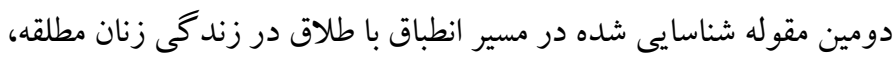

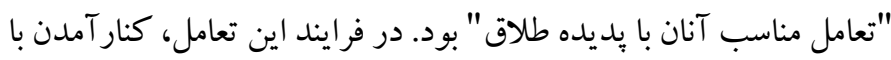

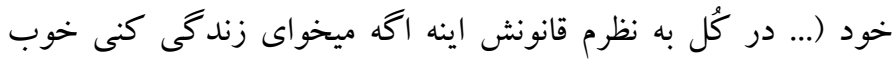
زندگى كن وگرنه خوب جدا شو ...)، كنار آمدن با همسر سابق (... ما از از

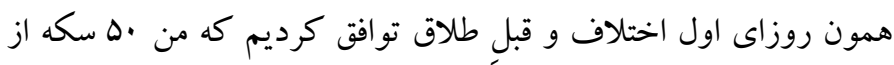

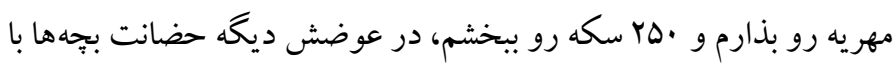

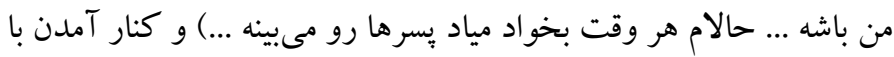

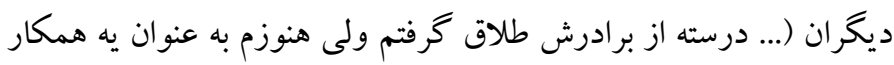

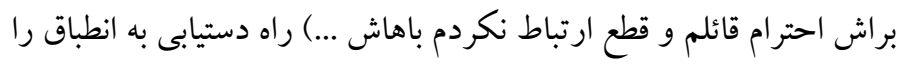
براى زنان مطلقه هموار كرده بود. در تأييد آنجه در اين مقوله كشف شئ شده

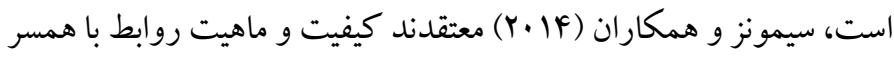

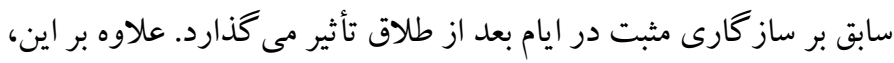

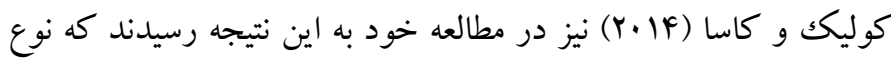
رابطه با همسر سابق، كمبود خصومت و اضطراب و يا رابطه دوستانه به

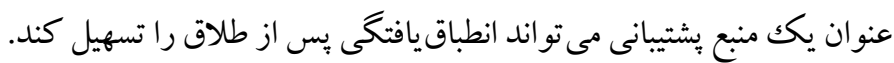

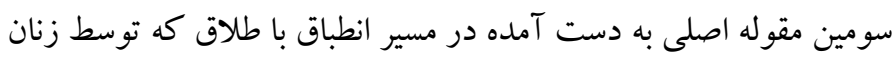
مطلقه روايت شد، "مديريت جالشهاى پِ بس از طلاق" بود. مديريت

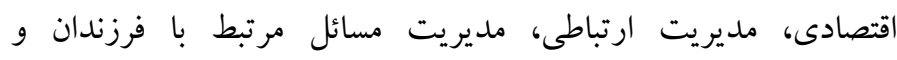




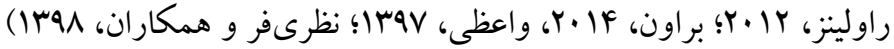

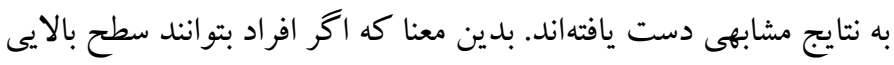

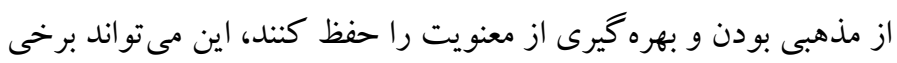
اثرات مخرب ارزيابى منفى از طلاق را كاهش دهد. همسو با اين نتايج،

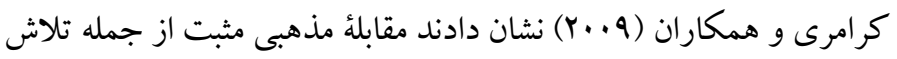

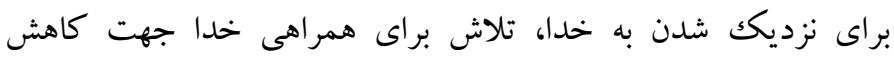

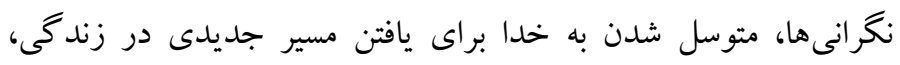

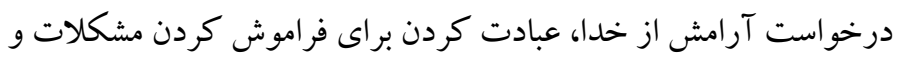

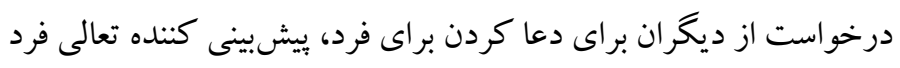

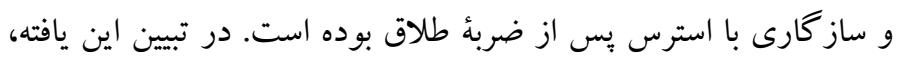

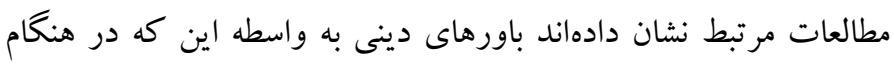

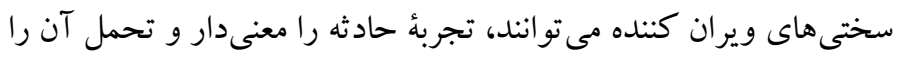

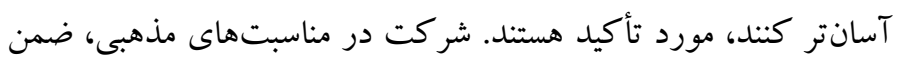

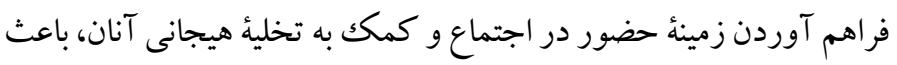

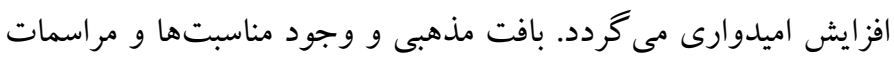

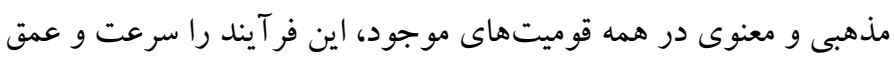

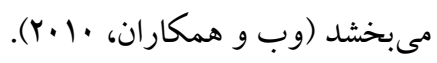

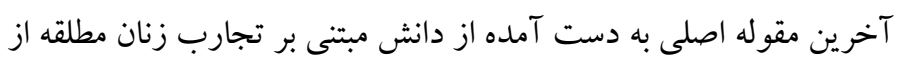

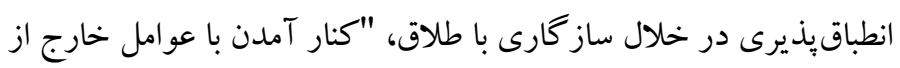
كنترل" بود. زنان مطلقه شركت كننده معتقد بودند كه برخدى بـ مسائل و و

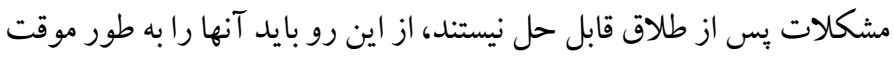

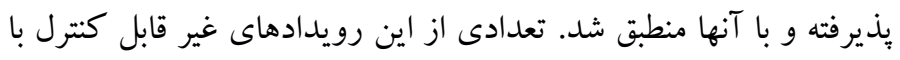

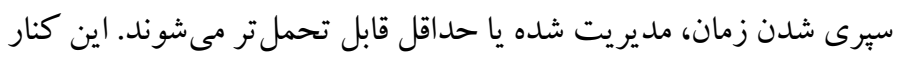

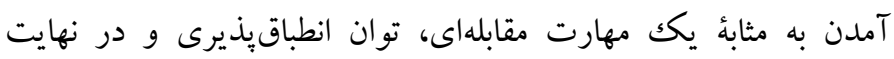

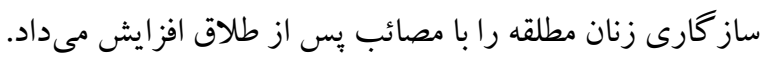

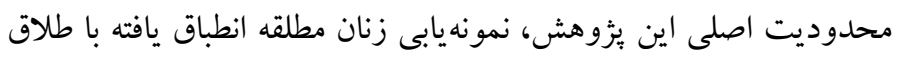

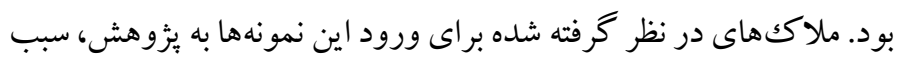

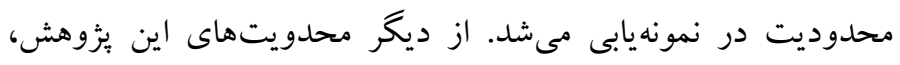

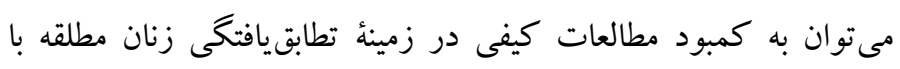

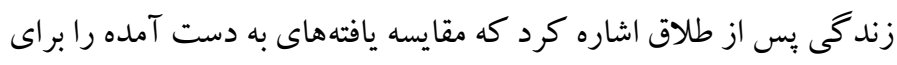
يثووهشَران با دشوارى روبرو مى ساخت. فهم دانش مبتى بر تجربه زنان

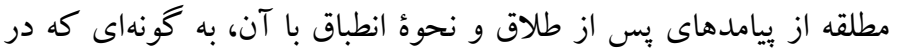

در ارتباط قرار گيرند كه داراى اهداف و علائق مشترك بوده و اين باعث تقويت شبكه اجتماعى آنان شده و مسير را براى حمايت متقابل ميسر

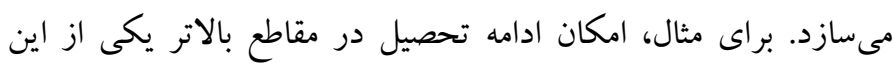
فعاليتهاى اجتماعى بود كه به عنوان سرمايهاى نهادى تلقى شده، زيرا

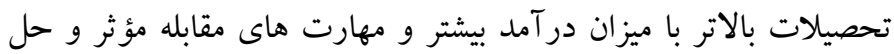

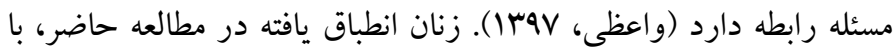
بازينى روابط اجتماعى، ايجاد مرزهاى رفتارى و حتى كاهى بنهان كران كردن

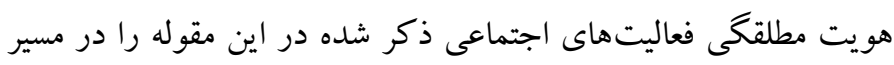

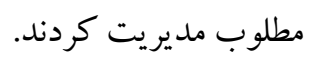
ينجمين مقوله اصلى شناسايى شده، "ضربه گيرها (عوامل محافظت كننده)"

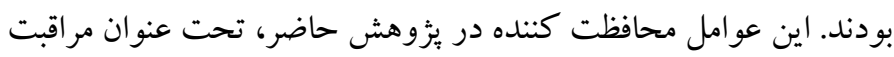
روانشناختى، خود گويىهاى معجزهآسا و مر اقبت هاى مادى و جسمانى در درو

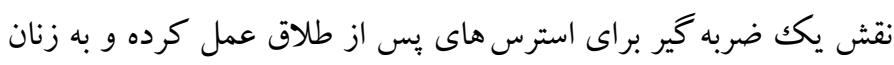

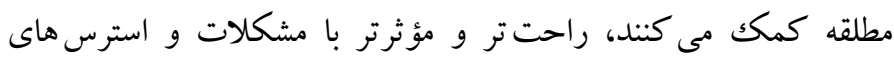

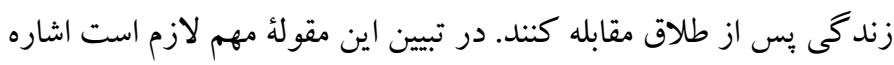

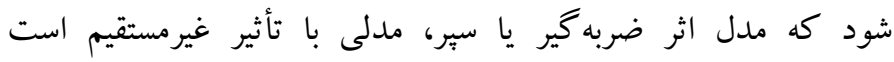

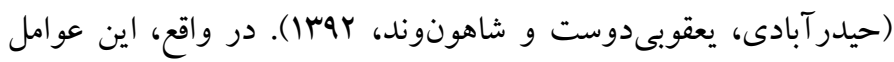

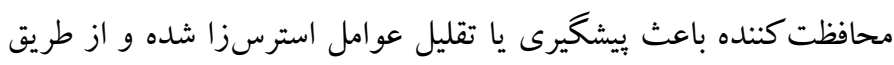

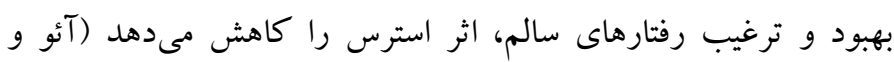

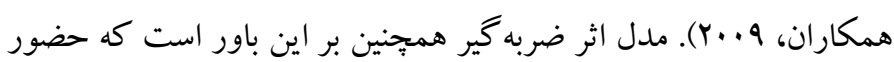

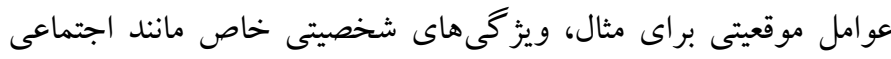

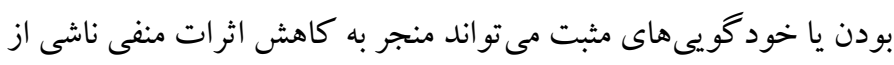

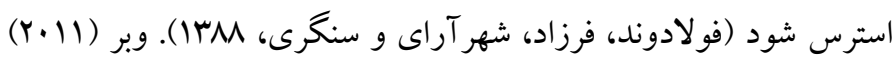

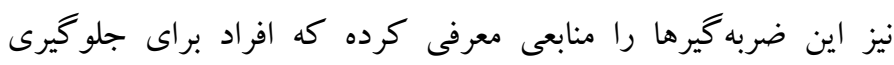

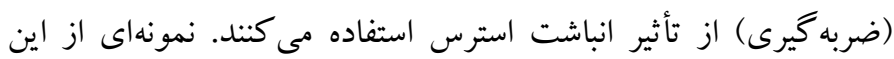

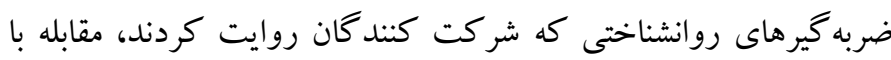

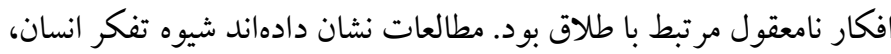

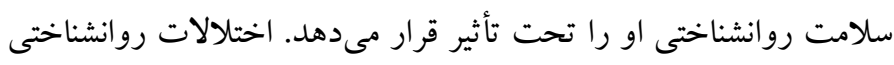

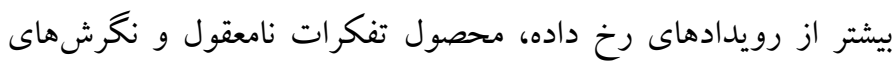
كز كارى است كه در تبيين و تفسير رويدادها نقش مهمى دارند.

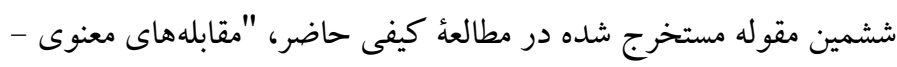

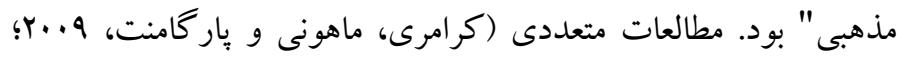




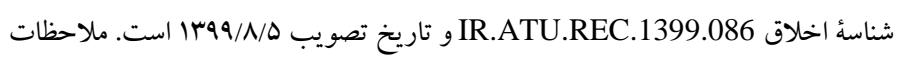
اخلاقى الزامى در اين يُزوهش شامل كسب رضايت آكاهانه از شركت كنند كان و اخذ

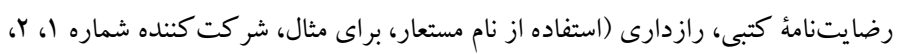
و... در تمام طول يثزوهش)، رعايت حريم شخصى و حق انصراف براى شر كت كنند كان بود.

حامى مالى: اين يثزوهش در قالب رساله دكترى و بدون حمايت مالى مىباشد. نقش هر يكك از نويسند كان: نويسنده اول، محقق اصلى اين يثزوهش است. نويسنده

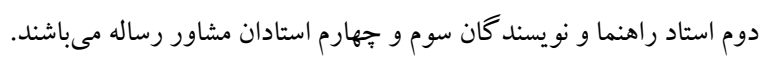

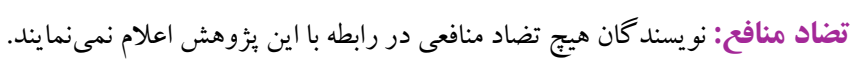
تشكر و قدردانى: از تمام زنان مطلقهاى كه در اين بثزوهش كيفى مشاركت كرده و تجارب زيستهان را صادقانه با ما در ميان گذاشتند، صميمانه قدردانى مى منمائيم.
مطالعه حاضر آمده است، مىتواند به زنان مطلقه و مشاوران و درمانگران

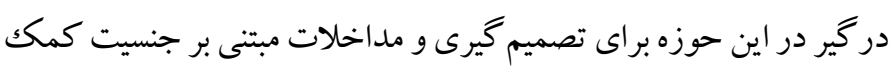
كند. نتايج به دست آمده همجينين مى تواند زمينه را براى تدوين برنامههاى بيشخير انه و درمانى جهت انطباق زنان مطلقه با دنياى يس ازطلاق فراهم كند. در نهايت اين كه مطالعه حاضر فقط بر روى زنان مطلقه انجام شد، لذا بيشنهاد مىشود، شناسايى راهبردهاى مؤثر بر انطباقيذيرى در فرآيند ساز كارى يس از طلاق در مورد مردان مطلقه نيز در يكك مطالعهُ كيفى مجزا

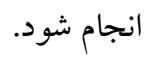

ملاحضات اخلاقى

يّيروى از اصول اخلاق يخوهش: مقاله حاضر مستخرج از رسالهُ دكترى نويسنده اول

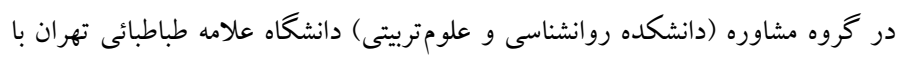




\section{References}

Amato, P. R. (2010). Research on divorce: Continuing trends and new developments. Journal of marriage and family, 72(3), 650-666. [Link]

Amato, P. R., \& Hohmann-Marriott, B. (2007). A comparison of high-and low-distress marriages that end in divorce. Journal of Marriage and Family, 69(3), 621-638. [Link]

Aartsen, M., \& Jylhä, M. (2011). Onset of loneliness in older adults: results of a 28 year prospective study. European Journal of Ageing, 8(1): 31-38. [Link]

Au, A., Lai, M. K., Lau, K. M., Pan, P. C., Lam, L., Thompson, L., \& Gallagher-Thompson, D. (2009). Social support and well-being in dementia family caregivers: The mediating role of self-efficacy. Aging \& Mental Health, 13(5), 761-768. [Link]

Bahrani F, Boland H, Sayadi A. Post Traumatic Growth Model in Divorced Women. MEJDS. 2019; 9:127127. [Link]

Bonanno, G. A., \& Mancini, A. D. (2008). The human capacity to thrive in the face of potential trauma. Pediatrics, 121(2), 369-375. [Link]

Braver, S. L., Shapiro, J. R., \& Goodman, M. R. (2006). Consequences of divorce for parents. Handbook of divorce and relationship dissolution, 313-337. [Link]

Brown, L. T. (2014). Bruised but not Broken: How coping styles, spirituality and social support are contributing factors to how well people do after divorce [Dissertation]. California State University. [link]

Cacioppo, J. T., Hawkley, L. C., \& Thisted, R. A. (2010). Perceived social isolation makes me sad: 5-year cross-lagged analyses of loneliness and depressive symptomatology in the Chicago Health, Aging, and Social Relations Study. Psychology and Aging, 25(2): 453-457. [Link]

Corbin, J., \& Strauss, A. (2014). Basics of qualitative research: Techniques and procedures for developing grounded theory. Sage publications. [Link]

Dehghan Menshadi, M., Zareei, E., Asgari, M., Naziri, G. (2017). The Effectiveness of the Metaphor Therapy and the Forgiveness Therapy on Women's Divorce Adjustment. Psychological Methods and Models, 8(27), 29-48. [Link]

Fooladvand KH, Farzad V, Shahraray M, Sangari A.A (2010). Role of social support, academic stress and academic self-efficacy on mental and physical health. Contemporary Psychology, 4 (2), 81-93. [Link]

Haedarabadi A., yaghoubidoust M, Shahvanvand B (2014). Studying the relationship between the perceived social support and domestic violence of parents with children. Journal of Socio - Cultural Changes, 10(4), 32-50. [Link]

Hetherington, E. M. (2003). Intimate pathways: Changing patterns in close personal relationships across time. Family relations, 52(4), 318-331. [Link]

Hewitt, B., \& Turrell, G. (2011). Short-term functional health and well-being after marital separation: Does initiator status make a difference?. American journal of epidemiology, 173(11), 1308-1318. [Link]

Iman, M. (2008). Human Being's Paradigm Analysis as the Main Component of Divine Paradigm Design. Methodology of Social Sciences and Humanities, 14(54), 25-46. (Persian). [Link]

JafariNadoushan A, Zare' H, hosseini Hanzaei A, poursalehi Navide M, Zeini M. (2015). Comparative Study of Mental Health, Adjustment, and Cognitive Emotion Regulation among Married Women and Divorcees in Yazd City. Quarterly Journal of Women and Society, 6(22), 1-16. [Link]

Kalmijn, M. (2010). Country differences in the effects of divorce on well-being: The role of norms, support, and selectivity. European Sociological Review, 26(4), 475-490. [Link]

Kavas, S. (2010). Post divorce experience of highly educated and professional women. Unpublished doctoral dissertation, Middle East Technical University Turkey. [Link]

Khalajabadi Farahani, F., Tanha, F., Abootorabi Zarchi, F. (2017). Life experience of divorced women in Saveh City in the scope of family and social relations. Women in Development \& Politics, 15(2), 223-240. [Link]

Khan, T. A., \& Hamid, W. (2020). Lived experiences of divorced women in Kashmir: a phenomenological study. Journal of Gender Studies, 1-16. [Link]

Knöpfli, B., Morselli, D., \& Perrig-Chiello, P. (2016). Trajectories of psychological adaptation to marital breakup after a long-term marriage. Gerontology, 62(5), 541-552. [Link]

Konstam, V., Karwin, S., Curran, T., Lyons, M., \& CelenDemirtas, S. (2016). Stigma and divorce: A relevant lens for emerging and young adult women? Journal of Divorce \& Remarriage, 57(3): 173-194. [Link]

Kulik, L., \& Kasa, Y. A. (2014). Adjustment to divorce: A compAarison of Ethiopian immigrant and Israeli born men. Journal of Community Psychology, 42(2), 191-208. [Link]

Kramrei, E., Coit, C., Martin, S., Fogo, W., \& Mahoney, A. (2007). Post-divorce adjustment and social relationships: A meta-analytic review. Journal of Divorce \& Remarriage, 46(3-4), 145-166. [Link]

Krumrei, E. J., Mahoney, A., \& Pargament, K. I. (2009). Divorce and the divine: The role of spirituality in 
adjustment to divorce. Journal of marriage and family, 71(2), 373-383. [Link]

Lloyd, G. M., Sailor, J. L., \& Carney, W. (2014). A phenomenological study of postdivorce adjustment in midlife. Journal of Divorce \& Remarriage, 55(6), 441-450. [Link]

Mandemakers, J. J., Monden, C. W., \& Kalmijn, M. (2010). Are the effects of divorce on psychological distress modified by family background?. Advances in Life Course Research, 15(1), 27-40. [Link]

Mirzazadeh, F., Ahmadi, K., fatehezadeh, M. (2012). Examining the Effectiveness of Emotionally Focused Therapy on post Divorce Adjustment in Women. Family Counseling and Psychotherapy, 2(1), 441-460. [Link]

Nazarifar, M., Sudani, M., Khojasteh Mehr, R., \& Farhadirad, H. (2020). A Post-divorce Adjustment Model for Women: A Research Based on Grounded Theory. Family Counseling and Psychotherapy, 2, 93-122. [Link]

Orth, U., Robins, R. W., \& Soto, C. J. (2010). Tracking the trajectory of shame, guilt, and pride across the life span. Journal of Personality and Social Psychology, 99(6): 1061-1069. [Link]

Perrig-Chiello, P., Hutchison, S., \& Morselli, D. (2015). Patterns of psychological adaptation to divorce after a long-term marriage. Journal of Social and Personal Relationships, 32(3), 386-405. [Link]

Rawlins, R. N. (2012). African/Caribbean-Canadian women coping with divorce: Family perspectives. University of Toronto (Canada). [Link]

Saadati N, Rostami M, Darbani S A. Comparing the effectiveness of Acceptance and Commitment Therapy (ACT) and Compassion Focused Therapy (CFT) on improving self-esteem and post-divorce adaptation in women. (2017). Ijfp, 3 (2):45-58. [Link]

Sabbaghi F, Salehi K, Moghadamzadeh A. (2017). Couples' Perceptions and Lived Experience of the Causes of Emotional Separation: A Phenomenological Study. QJCR.; 16 (62):4-31. [Link]

Sadeghi Fasa'i, S., Isari, M. (2013). Post-Divorce SelfRedefining and Identity Building in Women. Women Studies, 4(7), 111-138. [Link]

Shankar, A., Hamer, M., McMunn, A. and Steptoe, A. (2013) Social Isolation and Loneliness: Relationships with Cognitive Function during 4 Years of Follow-Up in the English Longitudinal Study of Ageing. Psychosomatic Medicine, 75, 161170. [Link]

Shankar, A., McMunn, A., Demakakos, P., Hamer, M., \& Steptoe, A. (2017). Social isolation and loneliness: Prospective associations with functional status in older adults. Health Psychology, 36(2): 179-183. [Link]

Streubert, H., \& Carpenter, D. (2011). Qualitative research in nursing (5th ed.). Philadelphia: Lippincott Williams \& Wilkins. [Link]

Symoens S, Van de Velde S, Colman E, Bracke P. (2014). Divorce and the multidimensionality of men and women's mental health: The role of socialrelational and socio-economic conditions. Appl Res Qual Life.; 9(2): 197-214. [Link]

Tashiro, T. Y., \& Frazier, P. (2003). "I'll never be in a relationship like that again": Personal growth following romantic relationship breakups. Personal Relationships, 10(1), 113-128. [Link]

Tedeschi, R. G., Park, C. L., \& Calhoun, L. G. (Eds.). (1998). Posttraumatic growth: Positive changes in the aftermath of crisis. Routledge. [Link]

Toussaint LL, Marschall JC, Williams DR. (2012). Prospective associations between religiousness/spirituality and depression and mediating effects of forgiveness in a nationally representative sample of United States adults Depress Res Treat: 267820. [Link]

Vaezi K. (2019). Coping Strategies of Women with PostDivorce Conditions. QJCR; 17 (68):172-191. [Link]

Vukalovich, D., \& Caltabiano, N. (2008). The effectiveness of a community group intervention program on adjustment to separation and divorce. Journal of Divorce \& Remarriage, 48(3-4), 145168. [Link]

Wang, H., \& Amato, P. R. (2000). Predictors of divorce adjustment: Stressors, resources, and definitions. Journal of Marriage and Family, 62(3), 655-668. [Link]

Weber, J. G. (2011). Individual and family stress and crises. Sage. [Link]

Webb, A. P., Ellison, C. G., McFarland, M. J., Lee, J. W., Morton, K., \& Walters, J. (2010). Divorce, religious coping, and depressive symptoms in a conservative protestant religious group. Family Relations, 59(5), 544-557. [Link]

Yárnoz-Yaben, S. (2010). Attachment style and adjustment to divorce. The Spanish Journal of Psychology, 13(1), 210-219. [Link]

Yousefi A, Sharifzadeh G R, Norozi E, Sahranavard S, Miri M R. (2019).The investigation adjustment status post-divorce and related factors in divorced women supported by the Birjand-based Relief Committee in 2018. J Birjand Univ Med Sci; 26 (4): 353-362. [Link]

Zare, S. A. Vafaie M. Ahmadi F. (2015). Spiritual encountering of divorced women in adjusting to the divorce phenomenon: A qualitative study. International Journal of Behavioral Sciences, 8(4), 395-403. [Link] 